\title{
New Perspectives to Repair A Broken Heart
}

\author{
R. Gaetani ${ }^{1, *}$, L. Barile $^{1}$, E. Forte ${ }^{1}$, I. Chimenti ${ }^{1}$, V. Ionta ${ }^{1}$, A. Di Consiglio ${ }^{1}$, F. Miraldi ${ }^{2}$, G. Frati ${ }^{3}$, \\ E. Messina ${ }^{1}$ and A. Giacomello ${ }^{1}$ \\ ${ }^{I}$ Department of Experimental Medicine, Cenci-Bolognetti Foundation, Pasteur Institute, University La Sapienza, \\ Rome, Italy; \\ ${ }^{2}$ Department of Heart and Great Vessels “Attilio Reale”, University La Sapienza, Rome, Italy; \\ ${ }^{3}$ Department of Heart and Great Vessels "Polo Pontino”, University La Sapienza, Rome, Italy
}

\begin{abstract}
The aim of cardiac cell therapy is to restore at least in part the functionality of the diseased or injured myocardium by the use of stem/progenitor cells. Recent clinical trials have shown the safety of cardiac cell therapy and encouraging efficacy results. A surprisingly wide range of non-myogenic cell types improves ventricular function, suggesting that benefits may result in part from mechanisms that are distinct from true myocardial regeneration. While clinical trials explore cells derived from skeletal muscle and bone marrow, basic researchers are investigating sources of new cardiomyogenic cells, such as resident myocardial progenitors and embryonic stem cells. In this commentary we briefly review the evolution of cell-based cardiac repair, some progress that has been made toward this goal, and future perspectives in the regeneration of cardiac tissue.
\end{abstract}

Key Words: Cardiac cell therapy, heart failure, stem cells, cardiac regeneration, cardiac stem cells.

\section{INTRODUCTION}

Congestive heart failure and coronary artery disease are the leading causes of morbidity and mortality in western society, despite recent advances in medical and device-based therapies. Limited strategies are available to address and counteract the central pathophysiologic process underlying the development of heart failure, which is the loss of cardiomyocytes, permanently compromising myocardial contractile function [1-3]. The injured heart heals by scar formation rather than by cardiomyocyte regeneration. Heart regeneration seems to be too inefficient to repair the extensive myocardial injury that occurs in human disease. Heart transplantation is currently the last chance for end-stage heart failure, but it is hampered by severe shortage of donor organs and rejection. Cell-based therapies are a promising alternative, given the basic assumption that left ventricular dysfunction is largely due to the loss of a critical number of cardiomyocytes and therefore it could be partly reversed by implantation of new contractile cells into the post-infarction scar. During the last few years cellular therapy for the diseased heart, using a variety of different cells, has shown encouraging results on cardiac function in animal models of heart ischemia, even without clear cardiovascular differentiation of the transplanted cells and without clear corresponding results in the first clinical trials.

In fact, while in the field of skin [4], cartilage [5], bone [6], adipose tissue [7, 8], and cornea [9], regenerative medicine (including cell therapy) is already well established and

*Address correspondence to this author at the Pasteur Institute (Fondazione Cenci Bolognetti), Department of Experimental Medicine, "Sapienza", University of Rome, viale Regina Elena, 32400161 Rome (Italy);

Tel/Fax: +39-06-4461481; E-mail: roberto.gaetani@uniroma1.it used clinically, therapeutic cardiac regeneration has to overcome some hurdles to be clinically feasible. We still need to develop efficient methods to selectively induce differentiation, to ensure cell yield, and to create transplantable tissue. The potential of cardiac cell therapy depends on the outcome of basic research and its application to the clinic.

In this review, a critical update will be presented on basic and clinical problems challenged by cardiac regenerative medicine, in particular by cell therapy. Furthermore, new perspectives on cardiac stem cells biology and their clinical deliverables will be discussed.

\section{CELLS EMPLOYED FOR EXPERIMENTAL CAR- DIAC REGENERATION}

The difficulty in regenerating damaged myocardial tissue has led researchers to explore the application of different stem cell types as possible sources for cell therapy, including embryonic stem cells (ESCs), cardiac stem cells (CSCs) that naturally reside within the heart, myoblasts (muscle stem cells), adult bone marrow (BM) derived cells, mesenchymal stem cells, endothelial progenitor cells, and umbilical cord blood cells. All have been tested in mouse or rat models, while some of them in large animal models as well, such as pigs, and in human clinical trials [10-14] (Table 1).

In the last five years the number of scientific publications concerning the experimental use of stem/progenitor cells for cardiac pathologies has grown up in a linear trend [15], with a slight decrease after 2006. This trend inversion reflects difficulties in finding adequate solutions to the many hurdles to be overcome for the clinical translation of a safe and effective cell therapy.

Many well-known problems exist and warrant further studies: the difficulty of inducing adult stem cells to cross 
Table 1. Stem Cell Populations Employed in Clinical Trials: Phenotype and In Vivo Results in Animal Models

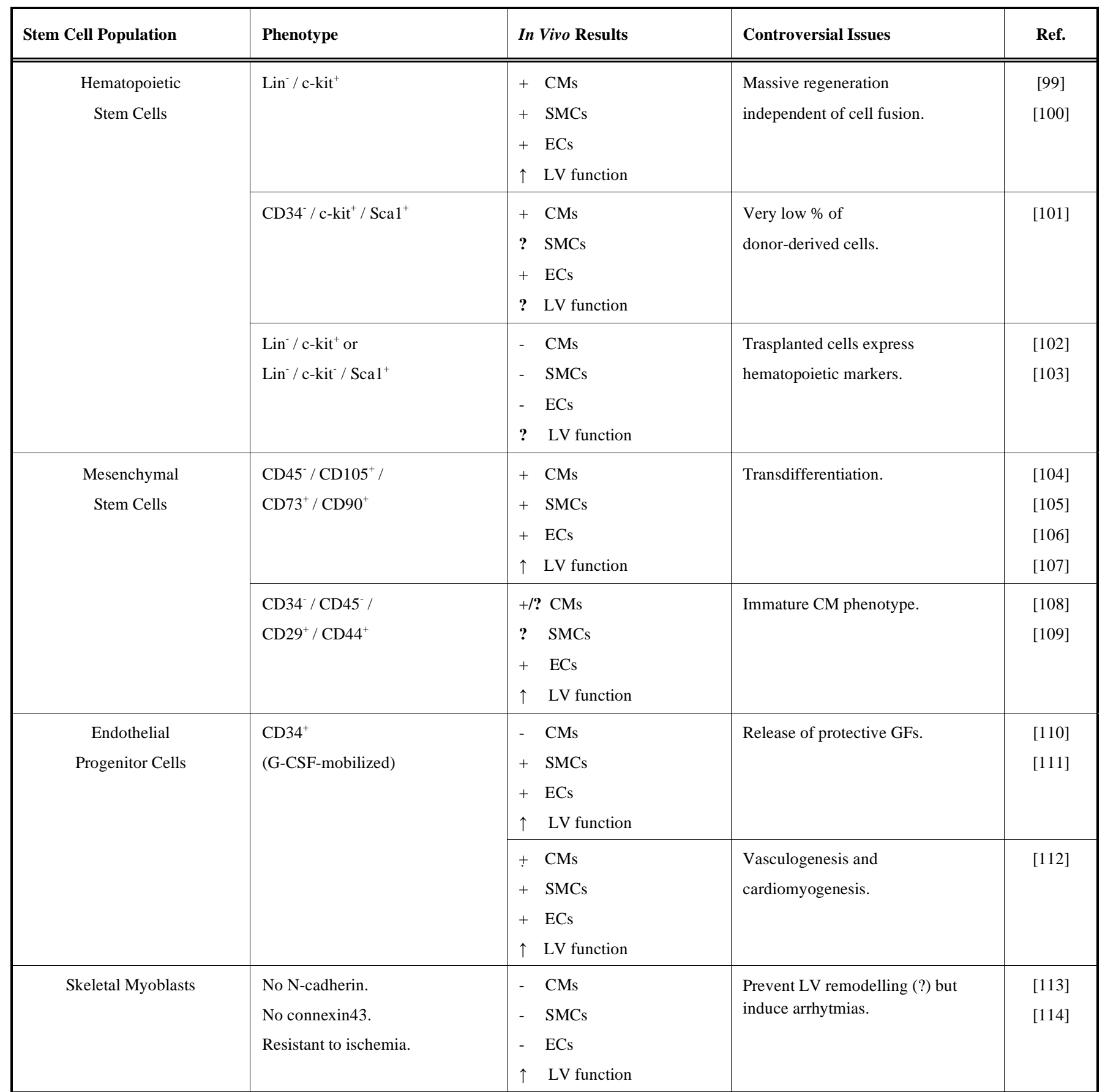

CMs: cardiomyocytes; SMCs: smooth muscle cells; ECs: endothelial cells; G-CSF: granulocyte-colony stimulating factor; LV: left ventricle; +: differentiate in; -: do not differentiate in; $\uparrow:$ improvement

their lineage boundaries (skeletal myoblasts and BM cells do not appear to transdifferentiate into cardiomyocytes); the commitment degree, the survival and the long-term retention of the injected cells and their properties (affecting adequate engraftment, proliferation, migration, differentiation and functional integration with the host); the timing and delivery strategies, also related to the specific heart pathology and to the patient to be treated.

In this contest, the paper of Zeisberg [16], showing that cardiac fibrosis is associated with the emergence of fibro- blasts originating from endothelial cells, could be considered a milestone because it addresses a process important for the critical evaluation of the long-term fate of any injected cell. In this study, in fact, TGF- $\beta$ release and endothelial-tomesenchymal transition have been suggested to contribute to the persistence of fibrosis, while BMP-7 was proposed as an inhibitor of the process, and therefore as a valuable therapeutic tool. The same mechanism however could have a role in the temporary functional effect elicited by almost all kinds of injected cells, particularly those employed in clinical trials. 
In other words, the cells to be used need to harbor a strong intrinsic and spontaneous potential of cardiac commitment, otherwise new scar will be added over the old one.

As previously suggested, the most appropriate cells for replacing dead cardiomyocytes appear to be cardiomyocytes of fetal or embryonic origin, since they can integrate functionally with resident myocardial cells [17]. This view is supported by experiments showing that transplanted fetal cardiac cells successfully engrafted into myocardial scars, connected with their host neighbors and improved function [18]. Moreover, in a recent study, Caspi [19] has shown that grafting of human ESC-derived cardiomyocytes into the normal and infarcted heart did not result in the generation of teratomas, as it occurs using undifferentiated ES cells. Instead the engrafted cardiomyocytes were shown to survive, proliferate, and integrate with host cardiac tissue [19]. However cardiomyocytes can not differentiate into coronary vessels, which obviously are also necessary for cardiac repair. Furthermore, their availability and scalability, in addition to immunological and ethical constraints, limit the use of fetal or embryonic tissue for any clinical application. Embryoniclike stem cells can be derived from neonatal and adult spermatogonial stem cells [20]. These cells have cardiac differentiation potential and could be used for autologous regenerative strategies without ethical and immunological problems [21]. Further studies are necessary to characterize these cells and to evaluate their behavior.

Another possible approach in cardiac repair concerns the use of mesothelial cells (MCs). MCs have an important role in the serosal homeostasis and repair after damage, and in preventing fibrous adhesion formation. Although MCs are of mesodermal origin, they show properties of both epithelial and mesenchymal phenotypes, displaying some degree of plasticity. MCs produce many cytokines and growth factors which can regulate inflammatory responses and stimulate tissue repair [22]. MCs also have the capacity to produce in vitro a variety of extracellular matrix macromolecules and to regulate their turnover [22].

Due to their multiple features and their endothelial properties, MCs are also used in tissue engineering and have been recently proposed as a cell source for cardiac repair. When transplanted into the damaged myocardium, MCs induced neoangiogenesis in the infarct scar and preserved heart function [23].

However, future studies warrant to fully understand their potential role and benefits for cardiac cell therapy.

Remarkable advances are also being made in generating pluripotent embryonic-like stem cells from somatic cells by viral expression of specific ESC-related genes and by somatic cell nuclear transfer [24].

The ideal cell to be transplanted for cardiac regeneration should probably be intermediate between a highly undifferentiated phenotype (ESCs) and a terminally differentiated cardiomyocyte. It should be characterized by a defined proliferative potential in the host without induction of immune reaction, by cardiac commitment and capacity to develop gap-junctions with the host cells, and should preferably be resistant to ischemia, in order to avoid massive cell death and apoptosis, that are currently among the biggest hurdles for cell therapy translation.

With these premises, it seems obvious that the best cells to replace lost cardiomyocytes may be cells derived from the heart itself.

\section{CARDIAC STEM CELLS AND CARDIAC REGEN- ERATION}

Emerging evidence suggests that several populations of stem/progenitor cells are present in the heart. A true cardiac stem/progenitor cell could be the ideal cell to repair a broken heart. However extensive basic research has yet to be performed to better understand the biology of these cells, that will foster the development of cell-based therapies for heart disease.

\section{Evidence and Controversies on Mammalian Heart Regeneration}

Typically, adult cardiac myocytes do not reenter the cell cycle when exposed to growth signals and further increase in cardiac mass during adulthood is achieved through hypertrophy. In contrast to most adult cardiomyocytes, fetal cardiomyocytes do proliferate. After birth, cardiomyocytes become binucleated, and withdraw from the cell cycle. Therefore adult mammalian cardiomyocytes have very limited potential for self renewal; the mammalian heart has historically been viewed as a terminally differentiated organ.

However the following observations lead to suggest that the mammalian heart has some potential intrinsic capacity to regenerate:

a. The presence of myocytes undergoing mitosis and cytokinesis has been demonstrated in human hearts, especially under pathologic conditions (myocardial infarction, late cardiac failure) [25].

b. Resident CSCs have been identified in the adult heart of humans and other mammal species (Table 2). These cells are self-renewing, clonogenic and multipotent, being able to differentiate into cardiomyocytes, smooth muscle and endothelial cells.

c. From a very elegant genetic fate-mapping study [26], an indirect evidence has been obtained that an undefined population of stem/progenitor cells could replace adult mammalian cardiomyocytes after injury. In this study the authors used double transgenic mice, in which tamoxifeninduceable Cre-recombinase was under the control of the MHC promoter, and a reporter cassette under the actin promoter. The reporter gene was lacZ flanked by loxsites, that would allow to switch to a GFP-reporter with induction of the Cre-recombinase. After a 4-OHtamoxifen pulse, GFP was expressed through the inducible Cre-Lox system only in differentiated MHCexpressing cells, resulting in $\sim 80 \%$ of GFP+ cardiomyocytes. After myocardial infarction (MI) or pressure overload, the percentage of GFP+ cardiomyocytes signifi cantly decreased, indicating that a putative stem/precursor cells, had refreshed the cardiomyocyte pool. 
Table 2. Resident Cardiac Stem Cells

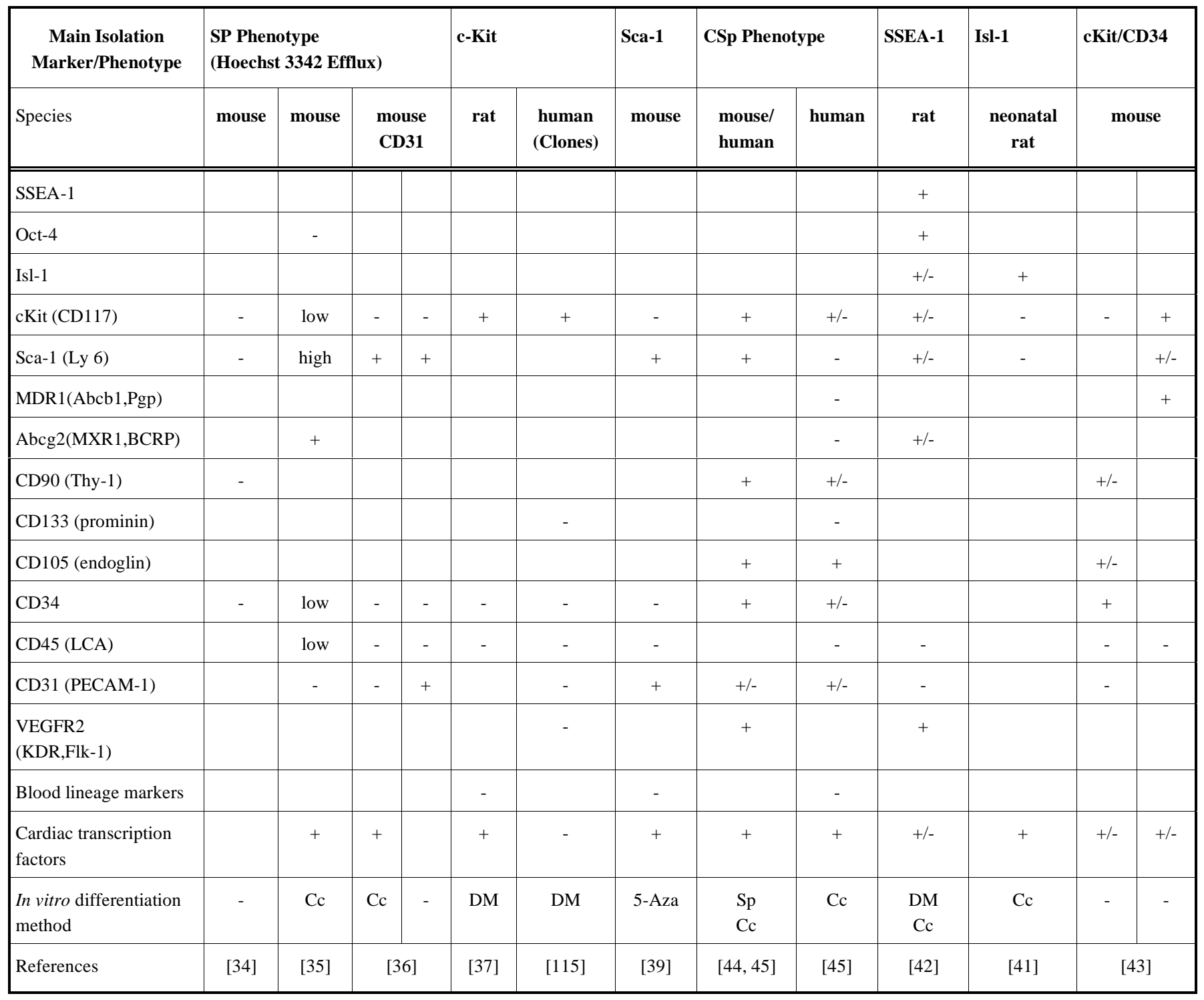

+/-: subset; Cc: co-colture; DM: differentiating media; 5-Aza: 5-azacytidine;

Sp: spontaneous. CSp: cardiosphere; SP: side population.

These studies indicate that, at least after injury, the heart has some limited capacity to regenerate and suggest that resident cardiac stem cells are involved in this process.

In the Hsieh study [26] it has been shown that in mice up to one year the percentage of GFP+ cardiomyocytes (that is the percentage of differentiated myocytes at the time of pulsing) remained unchanged, indicating no detectable replacement of cardiomyocytes by progenitor cells during normal aging. This observation supports the traditional view that cardiomyocytes are very long-living in the adult heart, and it is against the suggestion that the heart is a self-renewing organ in which myocyte regeneration occurs throughout the organism lifespan [27, 28].

However by following the ${ }^{14} \mathrm{C}$-dating of cardiac DNA, based on inadvertent pulse-labeling from atmospheric nuclear tests, it was demonstrated both in pre- and postatomic bomb born patients that, although the majority of cardiomyocytes are present from early development, their turnover is occurring during adulthood, at least until the third decade of life [29]. If cardiac regeneration occurs in the normal heart, the lack of detectable replacement of cardiomyocytes by progenitor cells during aging in the study by Hsieh could be explained (provided that these discrepancies could not be attributed to technical or methodological artifacts) assuming that cardiomyocytes are able to divide. Although it is generally accepted that cardiomyocytes loose their replicative capacity shortly after birth, it seems likely that the renewal of myocardial tissue during adult life might occur thanks to the ability of some cardiomyocytes to resume DNA synthesis and mitosis. This hypothesis is consistent with the observation that differentiated mononuclear cardio 
myocytes have some proliferative potential and reenter the cell cycle [30]. Adult cardiomyocytes of lower vertebrates (Anuria, Urodelia) proliferate considerably [31]. Zebrafish and newts hearts regenerate after injury with little or no scar formation. In newts regeneration occurs through dedifferentiation of specialized cells in blastema cells that redifferentiate afterwards into parenchimal cells [32]. In zebrafish, regeneration is supported by formation of blastema and by a subpopulation of epicardial cells [33]. Conversely the mammalian heart repairs itself poorly after infarction and regenerates poorly after injury.

\section{CSCs Discovery}

The discovery that the heart is not a terminally differentiated organ, but has a partial capacity to regenerate, gave a tremendous input in the last few years to the study of CSCs biology and increasing attention has been focused on the finding that the heart contains a reservoir of stem and progenitor cells [34-45]. These cells are positive for various stem/progenitor cell markers (c-Kit, Sca-1, Isl-1) and have Side Population (SP) properties. Although the relationship between the various CSCs and progenitor cells described awaits clarification (Table 2), nevertheless, they promise new therapeutic strategies for cardiac repair based on their regenerative potential. In fact, their presence into the heart, the frequent co-expression of early cardiac progenitor transcription factors, and the capability for ex vivo and in vivo differentiation towards the cardiac lineages offer the promise of enhanced cardiogenicity compared to other non-cardiac cell sources.

A well-known review by Garry and Olson [46] emphasizes a message shared by three recent studies [47-49], providing evidence for the existence during early development of cardiac progenitor cells that have the potential to differentiate in the three major cell types of the heart: myocytes, smooth muscle and endothelial cells. Beside the importance of each individual study, they raise still unresolved questions (relationship between the different progenitors described, variables in defining the differentiation pathway, markers and so on), particularly those related to the methods employed.

Due to the limited knowledge concerning the regulatory networks of proliferation, self renewal and lineage differentiation of cardiac progenitor cells, these studies tell us what is possible in our labs, but not necessarily what actually happens in vivo during development and disease. In other words, it is debatable to claim that one specific isolated cell is "the" only cardiac stem cell.

\section{Types of Resident Cardiac Stem and Progenitor Cells}

Different methods have been used to isolate CSCs from the heart, based on:

\section{The Ability to Efflux Hoescht Dye (Side Population)}

SP cells, which have the ability to efflux Hoechst dye, a process dependent on the expression of MDR1, Abcg2 or a comparable $\mathrm{ABC}$ transporter, have been identified in the developing, but also in the adult heart of mice [34, 35]. These cells are rare and their ability to differentiate into con- tracting cardiac myocytes or to contribute to functional repair of damaged heart muscle has not been extensively evaluated yet. Among cardiac SP cells, the greatest potential for cardiomyogenic differentiation is restricted to cells negative for CD31 and positive for stem cell antigen 1 (Sca1) expression [36].

\section{The Presence of Cell-Surface Stem Cell Markers (Either c- kit or Sca-1)}

In adult rat hearts a distinct population of CSCs has been isolated. These relatively small and primitive cells are negative for blood lineage markers and positive for c-kit, the receptor for the stem cell factor. These cells are self-renewing, clonogenic, and multipotent, giving rise to cardiomyocytes, smooth muscle and endothelial cells. When injected into the border zone of a 5-hour-old infarct in adult rats, these CSCs differentiated into newly formed myocardium, including cardiomyocytes, capillaries and arterioles in the infarcted area [37]. When delivered in a clinically relevant manner by intracoronary injection after a 90-minute coronary occlusion, followed by 4-hour reperfusion in rats, CSCs reduced the infarct, attenuated myocardial remodeling and ameliorated cardiac dysfunction 5 weeks after MI [38].

In the non-myocyte fraction of mice hearts, a resident population of CSCs, characterized by the expression of Sca1 , but lacking blood lineage markers or c-kit, has been reported $[39,40]$. Even though these cells do not spontaneously differentiate in vitro, when exposed to 5-azacytidine [39] or oxytocin [40] a small fraction of them demonstrates biochemical evidence of cardiac myocyte differentiation. After intravenous injection in mice subjected to myocardial ischemia-reperfusion, Sca-1+ cells homed to the heart and differentiated into cardiomyocytes, in part because of fusion with host cells [39].

\section{Expression of the Islet-1 Gene (isl1 + Cells)}

Another population of CSCs, characterized by the expression of the LIM-homeodomain transcription factor islet1 (isl1+ cells), has been recently described. These cells reside in the mature heart of newborn mice, rats and humans, and they are negative for c-kit or Sca-1, but express the early cardiac transcription factors Nkx2.5 and GATA4. When cocultured with cardiomyocytes, isl1+ cells convert very efficiently to mature cardiomyocytes without cell fusion [41]. However, their low abundance and mere presence in very young animals and humans prevent their short-term application. A challenge regarding this cell population is whether is $11+$ cells are present in the adult heart and whether they can be isolated, expanded, induced to differentiate or if they are able to regenerate damaged myocardium in vivo.

\section{Expression of the Stage-Specific Embryonic Antigen (SSEA-1+Cells)}

Recently uncommitted cardiac precursor cells (UPCs) have been identified in the heart of adult rats through a typical embryonic antigen, SSEA-1, that is expressed early in heart development [42]. SSEA-1+ cells isolated from adult rats differ from neonatal cells because they do not express cardiac specific transcription factors (Nkx2.5, GATA4). This 
suggests that only uncommitted stem cells persist in the adult heart. Adult UPCs in co-culture with cardiac-derived mesenchymal cells can differentiate in mature cardiomyocytes, endothelial cells, and smooth muscle cells through multiple stages, in which the cells co-express markers such as Oct4, Flk-1 or Sca-1 together with SSEA-1. Then, once commited, they finally express cardiac transcription factors such as Nkx2.5, GATA4 and Isl-1. Beating colonies are obtained by culturing UPCs in differentiating media or in co-culture with neonatal cardiomyocytes. UPCs improved ventricular function when injected in infarcted hearts, and SSEA-1+ cells are capable of forming new cardiomyocytes and endothelial cells in the infarct area [42].

\section{Epicardially Derived Cells (EPDCs)}

Limana [43] first identified cardiac progenitor cells outside of the previously described "niche" in human and mouse epicardium, which can migrate into the sub-epicardium where they generate a population of EPDCs. The authors described two distinct populations of myocardial and vascular precursor cells, expressing c-Kit or CD34 respectively [43]. Although c-Kit+ and CD34+ cells are negative for haematopoietic and endothelial markers (CD45-, CD31-), both populations have the ability to acquire the endothelial phenotype, as demonstrated by their capacity to uptake AcLDL-DiI, which is considered to be a specific marker for endothelial cells. A subset of c-Kit+ and CD34+ cells express cardiac transcription factors (Nkx2.5, GATA4). Their differentiation potential has been demonstrated only for cKit+ cells when a MI was induced in the mouse in the presence of an intact pericardial cavity.

\section{Cardiospheres: A Novel Method to Isolate CSCs}

Messina first debugged a methodology to isolate CSCs by primary culture of murine hearts or human heart tissue fragments derived from open heart surgery [44] (Fig. (1)). After few weeks of culture, a heterogeneous population of cells shed spontaneously from tissue fragments. Cells surrounding the "explants" express stem cell markers (c-Kit, Sca-1), endothelial progenitor cell antigens/markers (KDR, CD31) and the gap-junction protein Connexin43 (Cx43). They are clonogenic, and multipotent, giving rise spontane- ously to cardiomyocytes, smooth muscle and endothelial cells. In suspension culture they form spherical multicellular clusters dubbed "cardiospheres" (CSps). CSps consist of proliferating c-Kit-positive cells primarily in their core, and of differentiating cells expressing cardiac (MHC, NKx2.5, TnI, ANP), vascular (SMA), endothelial (vWF) and mesenchymal (CD105, CD90) cell markers on their periphery $[44,45]$.

The 3D-structure of CSps probably resembles the actual architecture of cardiac tissue, in terms of intra- and extracellular interactions, which may have a fundamental role in regulating cellular functions such as proliferation, differentiation and angiogenesis. In fact, differently from CSCs isolated with other methods, CSps can lead to terminally differentiated cardiomyocytes, as demonstrated by their ability to beat, either spontaneously (embryonic and neonatal murine CSps) or after co-culture with rat neonatal cardiomyocytes (pig, human, adult mice CSps). Moreover it seems likely that the protective microenvironment of the CSps could enable stem cells (or cells with stem-cell function) to retain their potency, as in the "niche" [50].

It has not yet been determined which are the antigens that could unequivocally identify CSp-forming cells. Experiments carried out using transgenic mice suggest that c-kit positive cells have a major role in CSps formation and growth. Although the intracardiac origin of CSCs and adult myocytes is generally accepted, GFP+ CSps were obtained 3-4 weeks after heart injury in lethally irradiated mice, whose BM had been repopulated by haematopoietic cells from a syngeneic c-kit/GFP animal [51]. This suggests that, at least under these conditions, BM cells could replenish the cardiac c-kit+ stem cell pool, acquiring functional characteristics of specialized CSCs, such as the capability to form CSps.

In order to increase cell yield, CSps can be expanded as adherent monolayers on fibronectin. Between 10 and 100 million cells can be obtained from a single biopsy in about 45 days [45]. Transplantation of human CSp-derived cells (CDCs) in the peri-infarct zone of SCID mice led to engraftment, migration, proliferation and multilineage differentiation, resulting in the replacement of dead tissue with new
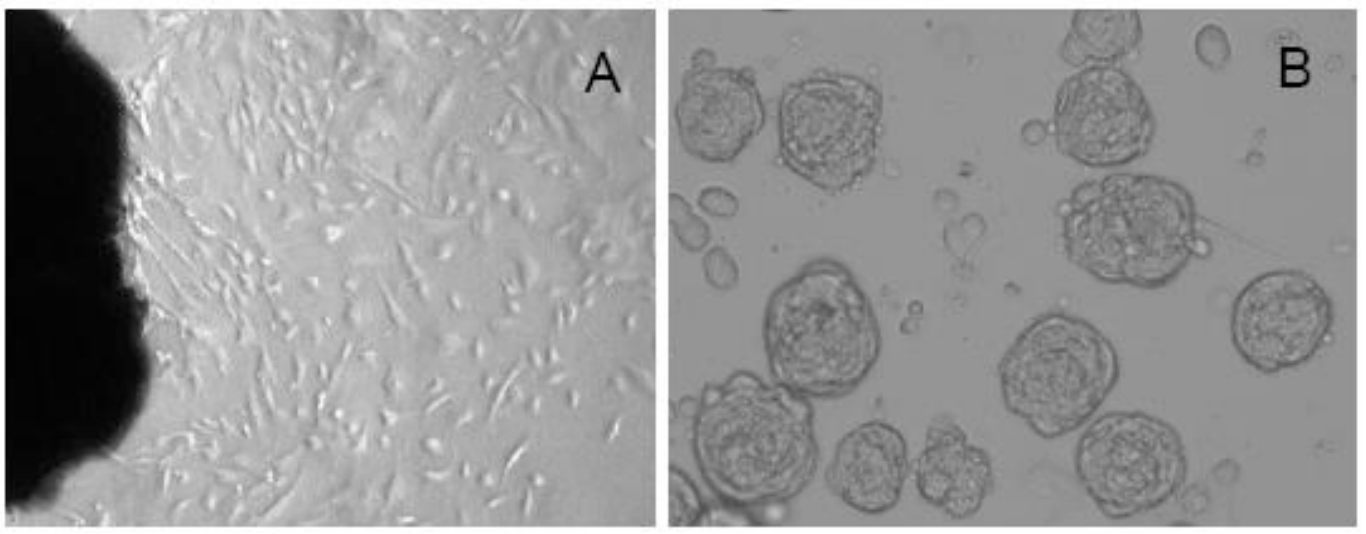

Fig. (1). Cardiosphere isolation steps. Explants are plated as primary cultures, and cells migrate from tissue fragments (A). CSp-forming cells are collected from the explant and then they spontaneously form floating CSps (B). 
myocardium and in functional improvement after 3 weeks [45].

There are many characteristics that make CSps different from other kinds of CSCs populations which have been isolated so far, in particular from those isolated by selection of a single putative stem cell marker.

- The CSp isolation protocol is based on intrinsic and spontaneous functional properties of the cells, which are the ability to migrate from tissue explants and to grow as 3D-structures, resembling somehow a niche-like microtissue.

- CSps can lead to terminal differentiation: embryonic and neonatal murine CSps can start beating spontaneously, while other CSCs need the addition of differentiating agents and/or co-culture with cardioyocytes in order to do so.

- CSps represent a heterogeneous population, including ckit positive stem-like cells and other cell types expressing mesenchymal markers: these latter, beside endothelial and fibroblast phenotypes, might also have a feeder-layer role, allowing the activation of multiple mechanisms for cardiac repair beyond myocyte formation (paracrine prosurvival effects, angiogenesis, mobilization of endogenous CSCs).

\section{TISSUE ENGINEERING}

In the past few years, cardiac tissue engineering (CTE) has emerged as a new approach to regenerate hearts damaged by myocardial infarction. CTE combines the use of biomaterials with cell biology and medicine. Several tissue engineering approaches are being explored for cardiac repair. In this review we briefly present an overview on the most promising materials and interesting approaches employed for CTE (for a complete review see Zamaretti [52], Zimmerman [53] and Jawad [54]).

The ideal biomaterial for CTE, either synthetic or natural, should enhance cell attachment, growth and differentiation. Moreover it should promote revascularization and have elettro-mechanical properties, allowing good integration with heart tissue. The most common approach for CTE is to seed cardiomyocytes onto pre-formed porous scaffolds made of polylactic acid, polyglycolic acid and their co-polymer polylactic-co-glycolic acid [55]. Other synthetic materials used in CTE are 1,3-trimethylene carbonate, D-L-lactide and their co-polymers [56], or the co-polymers $\varepsilon$-caprolactone-co-Llactide $[57,58]$.

A very exciting approach is the cell-sheeting method that involves cell culturing on temperature-responsive culture dishes. These dishes are made of poly-(N-isopropylacrylamide) (PIPAAm), which at $37^{\circ} \mathrm{C}$ is hydrophobic and promotes cell attachment. When temperature decreases to $32^{\circ} \mathrm{C}$ the polymer becomes hydrophilic and the cell sheet detaches from the plate. Shimizu et al. demonstrated that the detaching cell layers can be collected and, when layered one on top of the another, the sheets fuse, beat synchronously and become vascularized in vivo [59-61].
Several groups are currently working with scaffold materials made of natural polymers such as collagen, gelatin and alginate. Zimmermann et al. used a combination of liquid collagen type I and matrigel with neonatal cardiac myocytes cultured in persistent mechanical load $[62,63]$. Other approaches utilized a pre-formed, commercially available, tridimensional collagen matrix, obtaining promising results in terms of cardiac remodelling after implantation in an in vivo model of MI [64-70].

Chachques et al. reported the safety and feasibility of treatment with BMCs seeded onto a 3D collagen-type I-matrix in patients with left ventricular post-ischemic myocardial scar. The cell-seeded collagen matrix prevents cardiac remodeling and increases the thickness of the infarct scar with viable tissue, improving cardiac function $[69,71]$.

Another method that has emerged in the last years is an in situ CTE approach that involves injection of a mixture of biomaterials and cells. An example of this type of approach is the fibrin glue scaffold, consisting of two components: the first one consists of concentrated fibrinogen and aprotinin, and the second contains thrombin, $\mathrm{CaCl}_{2}$ and cells. When delivered in vivo with a Duploject applicator, that provides simultaneous mixing and delivery, the two components form a solid gel matrix that supports neo-angiogenesis, cell survival and decrease in infarct size [72, 73]. Other natural biomaterials used with this kind of approach are collagen I [74-77] and matrigel [74, 77, 78]. Finally a similar approach was applied by Davis et al. that injected "self assembling" peptide nanofibers into the myocardium for recruitment of progenitor cells and promotion of vasculogenesis [79].

\section{Clinical Trials}

Although experimental studies with BM stem cells in animal models gave rise to controversial results in terms of cardiac trans-differentiation and regeneration, they have been employed in several human clinical trials that took place in the last few years, and most of them are undergoing clinical evaluation (Table 3). BM is, at present, the most frequently used source of cells for clinical cardiac repair. In most clinical trials BM-derived cells or peripheral blood progenitor cells were transplanted both in patients with acute MI and chronic ischemic cardiomyopathy. Cell number, administration route and time of delivery also differed among studies. BM stem cells have been delivered in three ways, depending on the disease and pathological status of the patients: intracoronary cell delivery, catheter-based endocardial injection or direct intramyocardial implantation during open heart surgery [80-82].

All studies showed an excellent safety profile that was associated with a modest-to-low improvement in ventricular function, and only in few cases the injection of BMCs resulted in a consistent functional benefit (Table 4). Generally the advantage of intracoronary infusion is that cells migrate, via the microcirculation, to the perfused infarct region in a favourable environment for their survival, and this is a prerequisite for stable engraftment. On the other side, it limits their delivery only to the perfused regions and requires an increased number of cells to be administered. Moreover the 
Table 3. Protocol Details of Some of the Completed Clinical Trials for Cardiac Cell Therapy

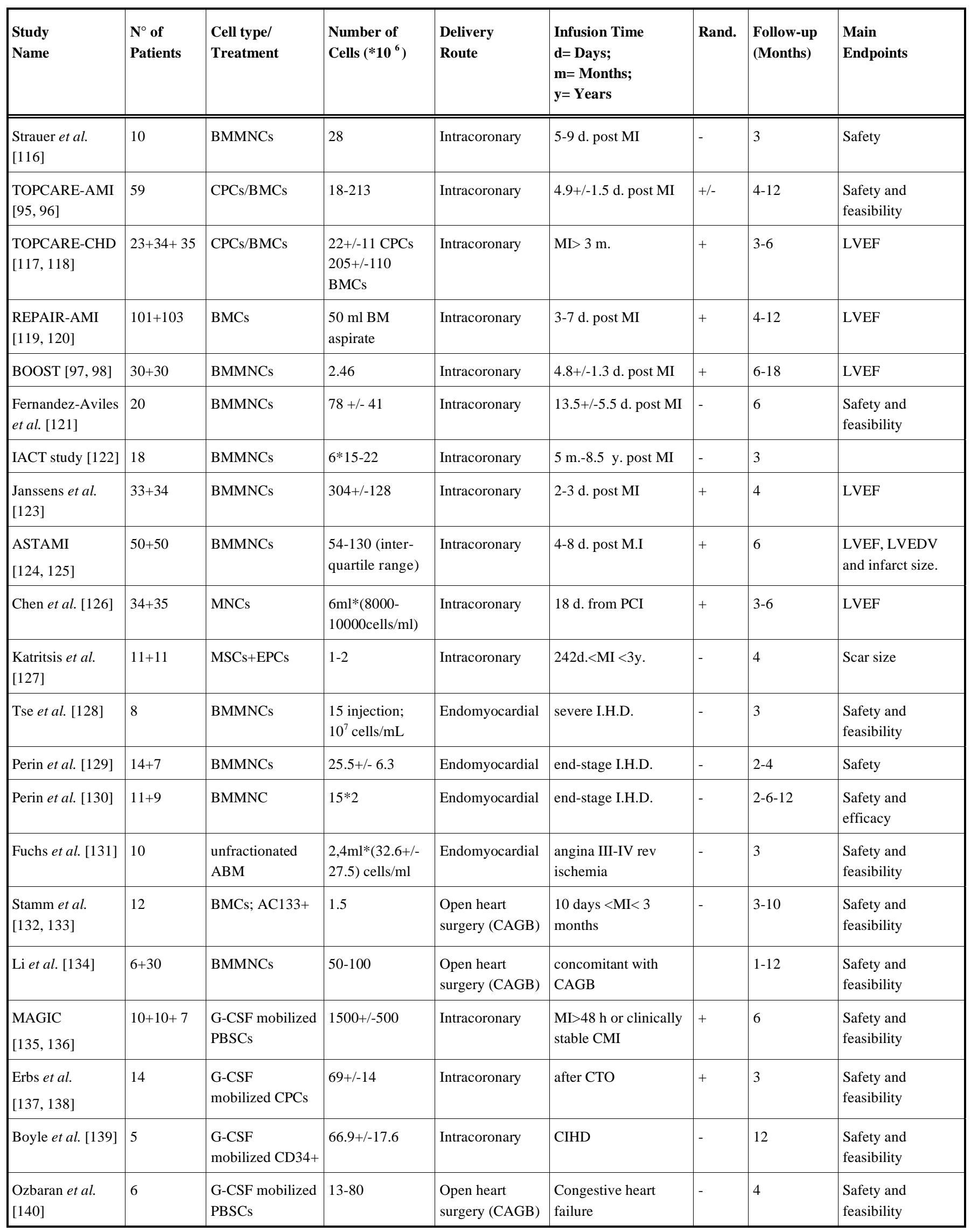


Table 3. Count....

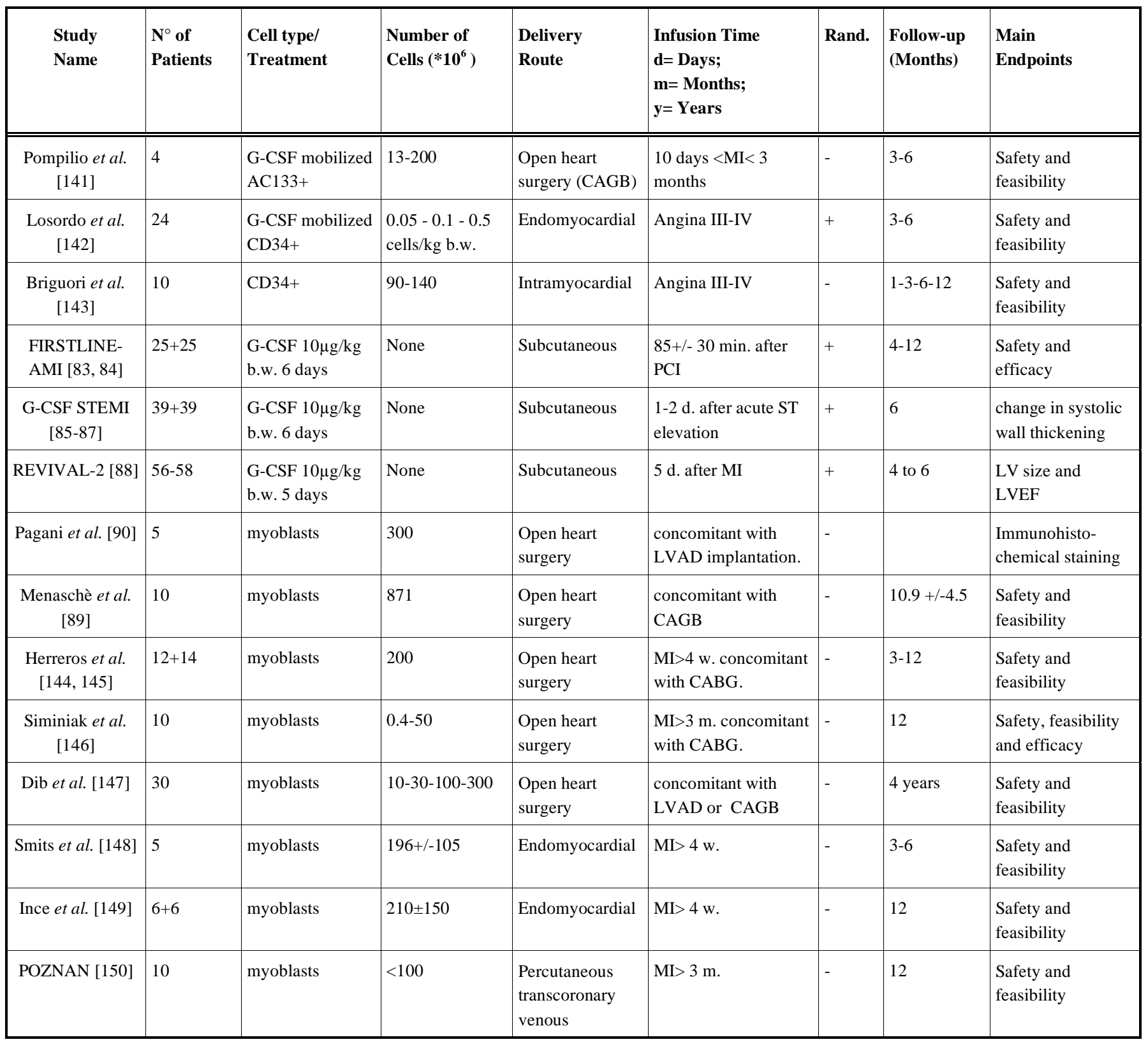

BMMNC: bone marrow mononuclear cell; CPC: circulating progenitor cell; EPC: endothelial progenitor cell; MSC: mesenchymal stem cell; GCSF: granulocyte colony stimulating factor; PBSC: peripheral blood stem cell; IHD: ischemic heart disease; CIHD: chronic ischemic heart disease; LVAD: left ventricular assist device; CAGB: coronary artery bypass grafting; CTO: recanalization of chronic coronary total occlusion; PCI: percutaneous coronary intervention; Rand: randomization. CMI: chronic myocardial infarction.

outcome after intracoronary route may be negatively affected by cell uptake from the circulation or by embolic risk. Another approach is to deliver cells directly into the scar tissue by catheter-based injection or during open heart surgery by multiple direct injections. However these methodologies are limited by the risk of ventricular perforation and they may induce arrhythmias.

A different approach is that of enhancing CSCs and progenitors activation and inducing their migration toward the infarct region by treatment with G-CSF. The rationale of this methodology derives from multiple studies in animal models (Table 1) and requires, for successful results, the reperfusion of the ischemic site. Briefly if we analyze different random- ized trials with G-CSF treatment after acute myocardial infarction, discrepancies arise again about the real beneficial effect on cardiac function [83-88]. Unfortunately, despite many relevant clinical trials have used BM stem cells or their mobilization, once again relevant doubts still remain about the therapeutic efficacy of these cells for cardiac regeneration (Table 4).

Autologous skeletal myoblasts are another potential source for cardiac repair. Skeletal myoblasts (SMs), or satellite cells, are the reservoir of regenerative cells for the skeletal muscle. SMs feature several attractive characteristics as therapeutic cells, including the autologous origin, which overcomes immunologic and ethical concerns. They can be 
Table 4. Improvement in Ventricular Function in Some Clinical Trials with Control Group

\begin{tabular}{|c|c|c|c|c|c|c|c|c|c|c|}
\hline Study & Treatment/ & \multicolumn{3}{|c|}{ LVEF\% } & \multicolumn{3}{|c|}{ LVESV } & \multicolumn{3}{|c|}{ LVEDV } \\
\hline \multirow{3}{*}{$\begin{array}{c}\text { REPAIR-AMI } \\
{[119,120]}\end{array}$} & months & Baseline & 4 & 12 & baseline & 4 & 12 & baseline & 4 & 12 \\
\hline & control & $46.9 \pm 10.4$ & $49.9 \pm 13.0$ & \multirow{2}{*}{$\begin{array}{l}\text { Clinical } \\
\text { outcome }\end{array}$} & $75 \pm 32$ & $80 \pm 45$ & \multirow{2}{*}{$\begin{array}{l}\text { Clinical } \\
\text { outcome }\end{array}$} & $139 \pm 46 \mathrm{ml}$ & $153 \pm 57 \mathrm{ml}$ & \multirow{2}{*}{$\begin{array}{l}\text { Clinical } \\
\text { outcome }\end{array}$} \\
\hline & BMCs & $48.3 \pm 9.2$ & $53.8 \pm 10.2$ & & $67 \pm 26$ & $67 \pm 30$ & & $128 \pm 38 \mathrm{ml}$ & $141 \pm 43 \mathrm{ml}$ & \\
\hline \multirow[t]{3}{*}{ BOOST $[97,98]$} & months & Baseline & 6 & 18 & baseline & 6 & 18 & baseline & 6 & 18 \\
\hline & control & $51.3 \pm 9.3$ & $52.0 \pm 12.4$ & $54.4 \pm 13.0$ & $\begin{array}{c}40.6 \pm 16.9 \\
\mathrm{ml} / \mathrm{m}^{2}\end{array}$ & $\begin{array}{c}42.6 \pm 23.5 \\
\mathrm{ml} / \mathrm{m}^{2}\end{array}$ & $\begin{array}{c}41.0 \pm 24.7 \\
\mathrm{ml} / \mathrm{m}^{2}\end{array}$ & $\begin{array}{c}81.4 \pm 16.9 \\
\mathrm{ml} / \mathrm{m}^{2}\end{array}$ & $\begin{array}{c}84.9 \pm 21.9 \\
\mathrm{ml} / \mathrm{m}^{2}\end{array}$ & $\begin{array}{c}85.0 \pm 24.2 \\
\mathrm{ml} / \mathrm{m}^{2}\end{array}$ \\
\hline & BMCs & $50.0 \pm 10.0$ & $56.7 \pm 12.5$ & $55.9 \pm 14.7$ & $\begin{array}{c}43.0 \pm 14.7 \\
\mathrm{ml} / \mathrm{m}^{2}\end{array}$ & $\begin{array}{c}42.4 \pm 23.9 \\
\mathrm{ml} / \mathrm{m}^{2}\end{array}$ & $\begin{array}{c}42.5 \pm 25.0 \\
\mathrm{ml} / \mathrm{m}^{2}\end{array}$ & $\begin{array}{c}84.2 \pm 17.2 \\
\mathrm{ml} / \mathrm{m}^{2}\end{array}$ & $\begin{array}{c}91.7 \pm 26.0 \\
\mathrm{ml} / \mathrm{m}^{2}\end{array}$ & $\begin{array}{c}90.3 \pm 26.5 \\
\mathrm{ml} / \mathrm{m}^{2}\end{array}$ \\
\hline \multirow[t]{3}{*}{ Janssens et al. [123] } & months & Baseline & \multicolumn{2}{|c|}{4} & baseline & \multicolumn{2}{|c|}{4} & baseline & \multicolumn{2}{|c|}{4} \\
\hline & control & $46.9 \pm 8.2$ & \multicolumn{2}{|c|}{$49.1 \pm 10.7$} & $\begin{array}{c}44.4 \pm 12.3 \\
\mathrm{ml} / \mathrm{m}^{2}\end{array}$ & \multicolumn{2}{|c|}{$45.0 \pm 17.9 \mathrm{ml} / \mathrm{m}^{2}$} & $\begin{array}{c}83.1 \pm 14.7 \\
\mathrm{ml} / \mathrm{m}^{2}\end{array}$ & \multicolumn{2}{|c|}{$85.9 \pm 19.5 \mathrm{ml} / \mathrm{m}^{2}$} \\
\hline & $\mathrm{BMCs}$ & $48.5 \pm 7.2$ & \multicolumn{2}{|c|}{$51.8 \pm 8.8$} & $\begin{array}{c}42.2 \pm 10.5 \\
\mathrm{ml} / \mathrm{m}^{2}\end{array}$ & \multicolumn{2}{|c|}{$41.0 \pm 15.5 \mathrm{ml} / \mathrm{m}^{2}$} & $\begin{array}{c}81.2 \pm 14.0 \\
\mathrm{ml} / \mathrm{m}^{2}\end{array}$ & \multicolumn{2}{|c|}{$84.1 \pm 20.8 \mathrm{ml} / \mathrm{m}^{2}$} \\
\hline \multirow{4}{*}{$\begin{array}{c}\text { TOPCARE-CHD } \\
{[117,118]} \\
*=\text { crossover to } \\
\text { another group } \\
\mathrm{CTR} \rightarrow \mathrm{BMC} / \mathrm{CPC} \\
\mathrm{CPCs} \rightarrow \mathrm{BMCs} \\
\mathrm{BMCs} \rightarrow \mathrm{CPCs}\end{array}$} & months & Baseline & 3 & $6 *$ & baseline & 3 & 6 & baseline & 3 & 6 \\
\hline & control & $43 \pm 13$ & $42 \pm 13$ & $\begin{array}{l}\text { Improve- } \\
\text { ment mainly }\end{array}$ & $55 \pm 36 \mathrm{ml} / \mathrm{m}^{2}$ & $\begin{array}{c}55 \pm 32 \\
\mathrm{ml} / \mathrm{m}^{2}\end{array}$ & - & $90 \pm 38 \mathrm{ml} / \mathrm{m}^{2}$ & $\begin{array}{c}87 \pm 33 \\
\mathrm{ml} / \mathrm{m}^{2}\end{array}$ & - \\
\hline & $\mathrm{CPCs}$ & $39 \pm 10$ & $39 \pm 10$ & treated. & $62 \pm 31 \mathrm{ml} / \mathrm{m}^{2}$ & $\begin{array}{c}60 \pm 26 \\
\mathrm{ml} / \mathrm{m}^{2}\end{array}$ & - & $96 \pm 34 \mathrm{ml} / \mathrm{m}^{2}$ & $93 \pm 30 \mathrm{ml} / \mathrm{m}^{2}$ & - \\
\hline & $\mathrm{BMCs}$ & $41 \pm 11$ & $43 \pm 10$ & & $49 \pm 26 \mathrm{ml} / \mathrm{m}^{2}$ & $\begin{array}{l}47 \pm 26 \\
\mathrm{ml} / \mathrm{m}^{2}\end{array}$ & - & $79 \pm 29 \mathrm{ml} / \mathrm{m}^{2}$ & $79 \pm 29 \mathrm{ml} / \mathrm{m}^{2}$ & - \\
\hline \multirow[t]{3}{*}{ ASTAMI $[124,125]$} & months & Baseline & \multicolumn{2}{|c|}{6} & Baseline & \multicolumn{2}{|c|}{6} & Baseline & \multicolumn{2}{|c|}{6} \\
\hline & control & $46.9 \pm 9.6$ & \multicolumn{2}{|c|}{$48.8 \pm 10.7$} & - & \multicolumn{2}{|c|}{ - } & $132.0 \pm 34.6$ & \multicolumn{2}{|c|}{$142.7 \pm 45.2$} \\
\hline & BMCs & $45 \pm 9.4$ & \multicolumn{2}{|c|}{$49.0 \pm 9.5$} & - & \multicolumn{2}{|c|}{-} & $136.1 \pm 30.5$ & \multicolumn{2}{|c|}{$145.0 \pm 42.0$} \\
\hline Chen et al. [126] & months & Baseline & 3 & 6 & baseline & 3 & 6 & baseline & 3 & 6 \\
\hline & control & $48 \pm 10$ & $53 \pm 18$ & $54 \pm 5$ & No difference & $88 \pm 19 \mathrm{ml}$ & - & No difference & $162 \pm 27 \mathrm{ml}$ & - \\
\hline & MSCs & $49 \pm 9$ & $67 \pm 11$ & $67 \pm 3$ & $\begin{array}{l}\text { between } \\
\text { groups }\end{array}$ & $63 \pm 20 \mathrm{ml}$ & & $\begin{array}{l}\text { between } \\
\text { groups }\end{array}$ & $136 \pm 31 \mathrm{ml}$ & \\
\hline Katritsis et al. [127] & months & Baseline & & & baseline & & & baseline & . & \\
\hline & control & $46.18 \pm 7.37$ & 47.7 & \pm 6.46 & $62.3 \pm 29.4$ & 59.23 & 21.35 & $121.2 \pm 35.2$ & 115.32 & 26.75 \\
\hline & MSCs+ EPCs & $41.5 \pm 7.7$ & 43.4 & \pm 6.65 & $69.1 \pm 24.0$ & 65.27 & 26.49 & $128.0 \pm 36.0$ & 119.45 & 36.98 \\
\hline Perin et al.[129] & months & baseline & & & baseline & & & baseline & rat & \\
\hline & control & $36 \pm 11.73$ & 31.8 & \pm 7.55 & $\begin{array}{c}89.42 \pm 26.23 \\
\mathrm{cc}\end{array}$ & $98.85 \pm$ & $0.52 \mathrm{cc}$ & $\begin{array}{l}135.71 \pm \\
26.08 \mathrm{cc}\end{array}$ & $145 \pm 2$ & $62 \mathrm{cc}$ \\
\hline & BMCs & $30 \pm 5.56$ & 35.5 & 7.85 & $\begin{array}{l}146.78 \pm \\
53.46 \mathrm{cc}\end{array}$ & 123.21 & $47.88 \mathrm{cc}$ & $\begin{array}{l}211.35 \pm \\
76.89 \mathrm{cc}\end{array}$ & $189.14 \pm$ & $7.54 \mathrm{cc}$ \\
\hline FIRSTLINE-AMI & month & baseline & 4 & 12 & - & - & - & & LVEDD & \\
\hline$[83,84]$ & & & & & & & & baseline & 4 & 12 \\
\hline & control & $47 \pm 5$ & $42 \pm 4$ & $45 \pm 8$ & - & - & - & $55 \pm 4 \mathrm{~mm}$ & $59 \pm 4 \mathrm{~mm}$ & $58 \pm 4 \mathrm{~mm}$ \\
\hline & G-CSF & $48 \pm 4$ & $54 \pm 8$ & $56 \pm 9$ & - & - & - & $55 \pm 3 \mathrm{~mm}$ & $54 \pm 5 \mathrm{~mm}$ & $54 \pm 5 \mathrm{~mm}$ \\
\hline
\end{tabular}


Table 4. Count....

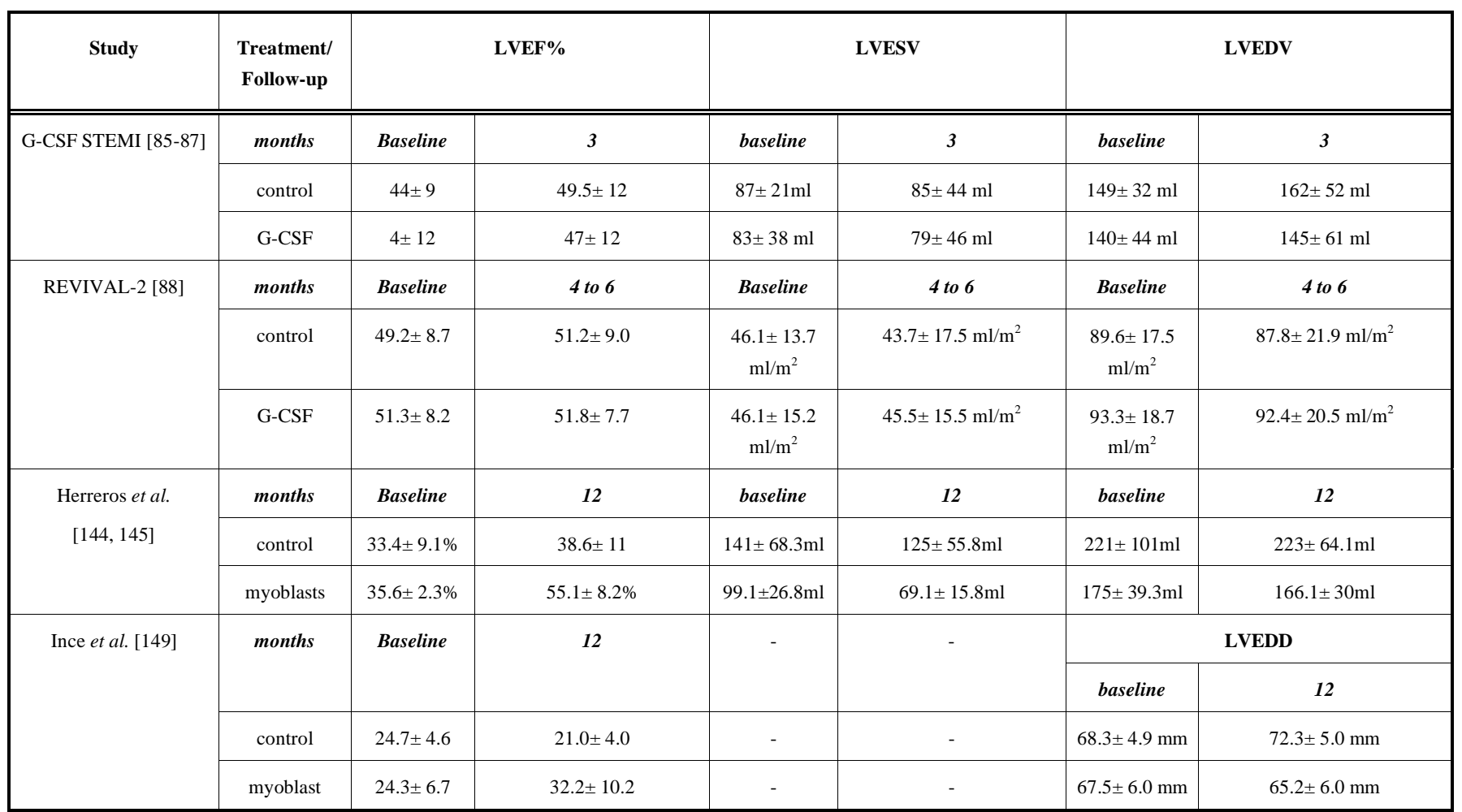

BMCs: bone marrow cells; CPCs: circulating progenitor cells; MSCs: mesenchymal stem cells; LVEF: left ventricle ejection fraction; LVESV: left ventricle end-systolic volume; LVEDV: left ventricle end-diastolic volume; LVEDD: left ventricle end-diastolic diameter.

readily isolated from relatively small skeletal muscle biopsies and amplified in an undifferentiated state in vitro. Promising experimental data in animal models of heart failure have led to several clinical trials, since June 2000 [89]. Although clinical trials have shown cell survival, differentiation toward a skeletal phenotype $[90,91]$ and improvement of global cardiac function following myoblasts injection (Table 3), they have also raised the issue of potential arrhythmogenicity [92]. Myoblast grafts represent arrhythmogenic foci because their electromechanical integration is limited by their inability to form gap-junctions [93], and also by their dihydropyridine phenotype, which markedly differs from that of cardiomyocytes. Myoblasts transplantation results in isolated islands of skeletal muscle tissue, mostly surrounded by scar tissue, so re-entry circuits can be formed and cause arrhytmias. It has also been proposed that some transplanted myoblasts might fuse with cardiomyocytes, thereby generating heterogeneity in calcium-signalling at the grafthost interface [94].

Generally the safety of cardiac cell therapy is well established, as well as its beneficial effects in terms of neovascularization and ventricular remodelling. However, long-term follow-up in most trials has shown that conventional pharmacological therapy has often the same outcome of cellular therapy [95-98] which probably works through indirect mechanisms. For example, it might decrease the death rate of the existing myocytes, improve neoangiogenesis or positively affect ventricular remodelling. The details of the possible mechanisms are unknown, but they could involve growth factors and cytokines secreted by the injected cells.
The small improvement in ventricular function though, especially in the long-term follow-up, is probably due to the inability of the cells to actually form new cardiomyocytes. It is also important to notice that all the differences in the trials protocols (number of injected cells, reperfusion time between ischemia and therapy, etc.) make it difficult to directly compare them one to the other.

\section{CONCLUDING REMARKS}

Extensive basic and clinical research performed during the last few years on cardiac regeneration and on the use of cell therapy to repair a broken heart led to two new important emerging concepts.

First, a large number of animal studies and clinical trials with different adult stem cells suggest that improved physiological function does not necessarily mean myocardial regeneration. After transplantation of non-cardiac cells that do not appear to transdifferentiate into new beating cardiomyocytes, beneficial functional effects have been observed. The potential mechanisms leading to improvement are highly debated and might involve reduction in ventricular remodeling after MI and/or paracrine effects that stimulate cell survival and angiogenesis. Considering the experience from the published clinical trials with non-cardiac stem/progenitor cells, a step backward to basic research study needs to be performed to better understand the real potential of the cells we are handling. In this regard, extensive studies have yet to be performed to better understand and control the selfrenewal and differentiation of these cells. Such knowledge could also be valuable to establish how to recruit CSCs al- 
ready residing in the heart by stimulating their proliferation and differentiation.

The second concept is that several subpopulations of cardiac stem/progenitor cells reside within the adult heart. These cells are self-renewing, clonogenic and multipotent, being able to differentiate into cardiomyocytes, endothelial and smooth muscle cells both in vitro and in vivo. The relationship between the various cardiac stem/progenitor cells described awaits clarification through comprehensive characterization and correlation of their origin, maintenance, and inherent reparative potential. Even if unable of massive regeneration, nonetheless these cells seem to participate in some kind of spontaneous attempt of heart regeneration after myocardial injury. However their ability to replace dead cardiomyocytes during normal aging has been questioned by a recent genetic fate-mapping study [26].

Theoretically a true cardiac progenitor cell would be the ideal cell type for the repair of a broken heart. Stem cells derived from a patient's own heart represent an attractive source for cellular transplantation and myocardial regeneration therapy. They are easily obtained in sufficient number from biopsy specimens and are capable of proliferation and differentiation into functional cardiomyocytes and vascular cells. Additionally, autologous CSCs can be used without immunosuppression. The possibility of using cardiac biopsy specimens as a source for ex vivo isolation and expansion of CSCs was introduced for the first time by our group [44, 45]. The expansion ex vivo over a period of weeks is necessary to obtain a sufficient number of cells for experimental and clinical purposes. Human CSCs, in the features of CSps or $\mathrm{CDCs}$, injected into the infarct border zone of SCID mice, promoted cardiomyocyte and vessels formation, and improvement in systolic function. Therefore, human CSps and CDCs represent attractive cell sources for cardiac repair, and display unique characteristics among CSCs. Because both ckit-positive cells and cells that express mesenchymal markers are present in CSps, they have the potential ability to improve function through several mechanisms. Indeed, in addition to new cardiomyocyte formation, improvements in cardiac function and increased regeneration within the infarct area could be attributed to paracrine effects, increased mobilization of endogenous CSCs and formation of new blood vessels.

Future clinical trials that will use stem cells for myocardial repair must focus at least on three concerns that are related to the delivery of these cells: 1) safety, 2) cell tracking to their ultimate destination(s) and 3) cost-efficiency ratio. While cell tracking technologies allow researchers to follow their migration patterns, stem cells must safely target their destination(s) and be retained there for the required time to achieve benefit. To facilitate targeting and enable clinical use, stem cells must be delivered easily and efficiently to their sites of application. Finally, the ease and the cost necessary for cell isolation and preparation will also impact the transition to the clinic of cardiac cell therapy.

\section{ACKNOWLEDGEMENTS}

This study was supported by MIUR, by the "Istituto Pasteur - Fondazione Cenci Bolognetti", and by the Department of Experimental Medicine, University "La Sapienza”, Roma (Italy).

\begin{tabular}{|c|c|c|}
\hline \multicolumn{3}{|c|}{ ABBREVIATIONS } \\
\hline ANP & $=$ & Atrial natriuretic peptide \\
\hline $\mathrm{BM}$ & $=$ & Bone marrow \\
\hline $\mathrm{CDC}$ & $=$ & Cardiosphere derived cell \\
\hline $\mathrm{CM}$ & $=$ & Cardiomyocyte \\
\hline $\mathrm{CPC}$ & $=$ & Circulating progenitor cell \\
\hline $\mathrm{CSC}$ & $=$ & Cardiac stem cell \\
\hline $\mathrm{CSp}$ & $=$ & Cardiosphere \\
\hline CTE & $=$ & Cardiac tissue engineering \\
\hline $\mathrm{Cx} 43$ & $=$ & Connexin 43 \\
\hline $\mathrm{EC}$ & $=$ & Endothelial cell \\
\hline EPC & $=$ & Endothelial progenitor cell \\
\hline EPDC & $=$ & Epicardially derived cell \\
\hline ESC & $=$ & Embryonic stem cell \\
\hline GCSF & $=$ & Granulocyte colony stimulating factor \\
\hline GFP & $=$ & Green fluorescent protein \\
\hline LV & $=$ & Left ventricle \\
\hline MC & $=$ & Mesothelial cell \\
\hline MHC & $=$ & Myosin heavy chain \\
\hline MI & $=$ & Myocardial infarction \\
\hline MSC & $=$ & Mesenchymal stem cell \\
\hline PBSC & $=$ & Peripheral blood stem cell \\
\hline Scal & $=$ & Stem cell antigen 1 \\
\hline SM & $=$ & Skeletal myoblast \\
\hline SMA & $=$ & Smooth muscle actin \\
\hline SMC & $=$ & Smooth muscle cell \\
\hline SP & $=$ & Side population \\
\hline SSEA1 & $=$ & Stage specific embryonic antigen 1 \\
\hline TnI & $=$ & Troponin I \\
\hline $\mathrm{PC}$ & $=$ & Uncommitted precursor cell \\
\hline & $=$ & von Willebrand factor \\
\hline
\end{tabular}

\section{REFERENCES}

[1] Dhalla, N.S.; Afzal, N.; Beamish, R.E.; Naimark, B.; Takeda, N.; Nagano, M. Pathophysiology of cardiac dysfunction in congestive heart failure. Can. J. Cardiol., 1993, 9(10), 873.

[2] Anversa, P.; Li, P.; Zhang, X.; Olivetti, G.; Capasso, J.M. Ischaemic myocardial injury and ventricular remodelling. Cardiovasc. Res., 1993, 27(2), 145.

[3] Udelson, J.E.; Patten, R.D.; Konstam, M.A. New concepts in postinfarction ventricular remodeling. Rev. Cardiovasc. Med., 2003, 4(Suppl. 3), S3.

[4] Burd, A.; Ahmed, K.; Lam, S.; Ayyappan, T.; Huang, L. Stem cell strategies in burns care. Burns, 2007, 33(3), 282. 
[5] Chen, F.H.; Rousche, K.T.; Tuan, R.S. Technology Insight: adult stem cells in cartilage regeneration and tissue engineering. Nat. Clin. Pract. Rheumatol., 2006, 2(7), 373.

[6] Corsi, K.A.; Schwarz, E.M.; Mooney, D.J.; Huard, J. Regenerative medicine in orthopaedic surgery. J. Orthop. Res., 2007, 25(10), 1261.

[7] Stosich, M.S.; Mao, J.J. Adipose tissue engineering from human adult stem cells: clinical implications in plastic and reconstructive surgery. Plast. Reconstr. Surg., 2007, 119(1), 71.

[8] Gomillion, C.T.; Burg, K.J. Stem cells and adipose tissue engineering. Biomaterials, 2006, 27(36), 6052.

[9] Inatomi, T.; Nakamura, T.; Koizumi, N.; Sotozono, C.; Kinoshita, $S$. Current concepts and challenges in ocular surface reconstruction using cultivated mucosal epithelial transplantation. Cornea., 2005, 24(8 Suppl.), S32.

[10] Boyle, A.J.; Schulman, S.P.; Hare, J.M.; Oettgen, P. Is stem cell therapy ready for patients? Stem Cell Therapy for Cardiac Repair. Ready for the Next Step. Circulation, 2006, 114(4), 339.

[11] Yoon, Y.S.; Lee, N.; Scadova, H. Myocardial regeneration with bone-marrow-derived stem cells. Biol. Cell, 2005, 97(4), 253.

[12] Laflamme, M.A.; Murry, C.E. Regenerating the heart. Nat. Biotechnol., 2005, 23(7), 845

[13] Guan, K.; Hasenfuss, G. Do stem cells in the heart truly differentiate into cardiomyocytes? J. Mol. Cell Cardiol., 2007, 43(4), 377.

[14] Christoforou, N.; Gearhart, J.D. Stem cells and their potential in cell-based cardiac therapies. Prog. Cardiovasc. Dis., 2007, 49(6), 396.

[15] Kocher, A.A.; Schlechta, B.; Gasparovicova, A.; Wolner, E.; Bonaros, N.; Laufer, G. Stem cells and cardiac regeneration. Transpl. Int., 2007, 20(9), 731.

[16] Zeisberg, E.M.; Tarnavski, O.; Zeisberg, M.; Dorfman, A.L.; McMullen, J.R.; Gustafsson, E.; Chandraker, A.; Yuan, X.; Pu, W.T.; Roberts, A.B.; Neilson, E.G.; Sayegh, M.H.; Izumo, S.; Kalluri, R. Endothelial-to-mesenchymal transition contributes to cardiac fibrosis. Nat. Med., 2007, 13(8), 952.

[17] Siu, C.W.; Moore, J.C.; Li, R.A. Human embryonic stem cellderived cardiomyocytes for heart therapies. Cardiovasc. Hematol. Disord. Drug Targets, 2007, 7(2), 145.

[18] Skobel, E.; Schuh, A.; Schwarz, E.R.; Liehn, E.A.; Franke, A.; Breuer, S.; Gunther, K.; Reffelmann, T.; Hanrath, P.; Weber, C. Transplantation of fetal cardiomyocytes into infarcted rat hearts results in long-term functional improvement. Tissue Eng., 2004, 10(5-6), 849 .

[19] Caspi, O.; Huber, I.; Kehat, I.; Habib, M.; Arbel, G.; Gepstein, A.; Yankelson, L.; Aronson, D.; Beyar, R.; Gepstein, L. Transplantation of human embryonic stem cell-derived cardiomyocytes improves myocardial performance in infarcted rat hearts. J. Am. Coll. Cardiol., 2007, 50(19), 1884.

[20] Guan, K.; Nayernia, K.; Maier, L.S.; Wagner, S.; Dressel, R.; Lee, J.H.; Nolte, J.; Wolf, F.; Li, M.; Engel, W.; Hasenfuss, G. Pluripotency of spermatogonial stem cells from adult mouse testis. Nature, 2006, 440(7088), 1199.

[21] Guan, K.; Wagner, S.; Unsold, B.; Maier, L.S.; Kaiser, D.; Hemmerlein, B.; Nayernia, K.; Engel, W.; Hasenfuss, G. Generation of functional cardiomyocytes from adult mouse spermatogonial stem cells. Circ. Res., 2007, 100(11), 1615.

[22] Herrick, S.E.; Mutsaers, S.E. The potential of mesothelial cells in tissue engineering and regenerative medicine applications. Int. J. Artif. Organs, 2007, 30(6), 527.

[23] Elmadbouh, I.; Chen, Y.; Louedec, L.; Silberman, S.; Pouzet, B.; Meilhac, O.; Michel, J.B. Mesothelial cell transplantation in the infarct scar induces neovascularization and improves heart function. Cardiovasc. Res., 2005, 68(2), 307.

[24] Yu, J.; Vodyanik, M.A.; Smuga-Otto, K.; Antosiewicz-Bourget, J.; Frane, J.L.; Tian, S.; Nie, J.; Jonsdottir, G.A.; Ruotti, V.; Stewart, R.; Slukvin, II; Thomson, J. A. Induced pluripotent stem cell lines derived from human somatic cells. Science, 2007, 318(5858), 1917.

[25] Beltrami, A.P.; Urbanek, K.; Kajstura, J.; Yan, S.M.; Finato, N.; Bussani, R.; Nadal-Ginard, B.; Silvestri, F.; Leri, A.; Beltrami, C.A.; Anversa, P. Evidence that human cardiac myocytes divide after myocardial infarction. N. Engl. J. Med., 2001, 344(23), 1750.

[26] Hsieh, P.C.; Segers, V.F.; Davis, M.E.; MacGillivray, C.; Gannon, J.; Molkentin, J.D.; Robbins, J.; Lee, R.T. Evidence from a genetic fate-mapping study that stem cells refresh adult mammalian cardiomyocytes after injury. Nat. Med., 2007, 13(8), 970.
[27] Chen, X.; Wilson, R.M.; Kubo, H.; Berretta, R.M.; Harris, D.M.; Zhang, X.; Jaleel, N.; MacDonnell, S.M.; Bearzi, C.; Tillmanns, J.; Trofimova, I.; Hosoda, T.; Mosna, F.; Cribbs, L.; Leri, A.; Kajstura, J.; Anversa, P.; Houser, S.R. Adolescent feline heart contains a population of small, proliferative ventricular myocytes with immature physiological properties. Circ. Res., 2007, 100(4), 536.

[28] Rota, M.; Hosoda, T.; De Angelis, A.; Arcarese, M.L.; Esposito, G.; Rizzi, R.; Tillmanns, J.; Tugal, D.; Musso, E.; Rimoldi, O.; Bearzi, C.; Urbanek, K.; Anversa, P.; Leri, A.; Kajstura, J. The young mouse heart is composed of myocytes heterogeneous in age and function. Circ. Res., 2007, 101(4), 387.

[29] Bhardwaj, R.D. Cytoarcheology: understanding cellular turnover in the human brain and hear. Dissertations from Karolinska Institutet, 2007, (ISBN: 978-91-7357-130-2 ).

[30] Kuhn, B.; del Monte, F.; Hajjar, R.J.; Chang, Y.S.; Lebeche, D.; Arab, S.; Keating, M.T. Periostin induces proliferation of differentiated cardiomyocytes and promotes cardiac repair. Nat. Med., 2007, 13(8), 962.

[31] Curado, S.; Stainier, D.Y. The HeArt of regeneration. Cell, 2006, 127(3), 462.

[32] Laube, F.; Heister, M.; Scholz, C.; Borchardt, T.; Braun, T. Reprogramming of newt cardiomyocytes is induced by tissue regeneration. J. Cell Sci., 2006, 119(Pt 22), 4719.

[33] Lepilina, A.; Coon, A.N.; Kikuchi, K.; Holdway, J.E.; Roberts, R.W.; Burns, C.G.; Poss, K. D. A dynamic epicardial injury response supports progenitor cell activity during zebrafish heart regeneration. Cell, 2006, 127(3), 607.

[34] Hierlihy, A.M.; Seale, P.; Lobe, C.G.; Rudnicki, M.A.; Megeney, L.A. The post-natal heart contains a myocardial stem cell population. FEBS Lett., 2002, 530(1-3), 239.

[35] Martin, C.M.; Meeson, A.P.; Robertson, S.M.; Hawke, T.J.; Richardson, J.A.; Bates, S.; Goetsch, S.C.; Gallardo, T.D.; Garry, D.J. Persistent expression of the ATP-binding cassette transporter, Abcg2, identifies cardiac SP cells in the developing and adult heart. Dev. Biol., 2004, 265(1), 262.

[36] Pfister, O.; Mouquet, F.; Jain, M.; Summer, R.; Helmes, M.; Fine, A.; Colucci, W.S.; Liao, R. CD31- but Not CD31+ cardiac side population cells exhibit functional cardiomyogenic differentiation. Circ. Res., 2005, 97(1), 52.

[37] Beltrami, A.P.; Barlucchi, L.; Torella, D.; Baker, M.; Limana, F.; Chimenti, S.; Kasahara, H.; Rota, M.; Musso, E.; Urbanek, K.; Leri, A.; Kajstura, J.; Nadal-Ginard, B.; Anversa, P. Adult cardiac stem cells are multipotent and support myocardial regeneration. Cell, 2003, 114(6), 763.

[38] Dawn, B.; Stein, A.B.; Urbanek, K.; Rota, M.; Whang, B.; Rastaldo, R.; Torella, D.; Tang, X. L.; Rezazadeh, A.; Kajstura, J.; Leri, A.; Hunt, G.; Varma, J.; Prabhu, S.D.; Anversa, P.; Bolli, R. Cardiac stem cells delivered intravascularly traverse the vessel barrier, regenerate infarcted myocardium, and improve cardiac function. Proc. Natl. Acad. Sci. USA, 2005, 102(10), 3766.

[39] Oh, H.; Bradfute, S.B.; Gallardo, T.D.; Nakamura, T.; Gaussin, V.; Mishina, Y.; Pocius, J.; Michael, L.H.; Behringer, R.R.; Garry, D.J.; Entman, M.L.; Schneider, M.D. Cardiac progenitor cells from adult myocardium: homing, differentiation, and fusion after infarction. Proc. Natl. Acad. Sci. USA, 2003, 100(21), 12313.

[40] Matsuura, K.; Nagai, T.; Nishigaki, N.; Oyama, T.; Nishi, J.; Wada, H.; Sano, M.; Toko, H.; Akazawa, H.; Sato, T.; Nakaya, H.; Kasanuki, H.; Komuro, I. Adult cardiac Sca-1-positive cells differentiate into beating cardiomyocytes. J. Biol. Chem., 2004, 279(12), 11384.

[41] Laugwitz, K.L.; Moretti, A.; Lam, J.; Gruber, P.; Chen, Y.; Woodard, S.; Lin, L.Z.; Cai, C.L.; Lu, M.M.; Reth, M.; Platoshyn, O.; Yuan, J.X.; Evans, S.; Chien, K.R. Postnatal isl1+ cardioblasts enter fully differentiated cardiomyocyte lineages. Nature, 2005, 433(7026), 647.

[42] Ott, H.C.; Matthiesen, T.S.; Brechtken, J.; Grindle, S.; Goh, S.K.; Nelson, W.; Taylor, D.A. The adult human heart as a source for stem cells: repair strategies with embryonic-like progenitor cells. Nat. Clin. Pract. Cardiovasc. Med., 2007, 4(Supp.1 ), S27.

[43] Limana, F.; Zacheo, A.; Mocini, D.; Mangoni, A.; Borsellino, G.; Diamantini, A.; De Mori, R.; Battistini, L.; Vigna, E.; Santini, M.; Loiaconi, V.; Pompilio, G.; Germani, A.; Capogrossi, M.C. Identification of myocardial and vascular precursor cells in human and mouse epicardium. Circ. Res., 2007, 101(12), 1255.

[44] Messina, E.; De Angelis, L.; Frati, G.; Morrone, S.; Chimenti, S.; Fiordaliso, F.; Salio, M.; Battaglia, M.; Latronico, M.V.; Coletta, 
M.; Vivarelli, E.; Frati, L.; Cossu, G.; Giacomello, A. Isolation and expansion of adult cardiac stem cells from human and murine heart. Circ. Res., 2004, 95(9), 911.

[45] Smith, R.R.; Barile, L.; Cho, H.C.; Leppo, M.K.; Hare, J.M.; Messina, E.; Giacomello, A.; Abraham, M.R.; Marban, E. Regenerative potential of cardiosphere-derived cells expanded from percutaneous endomyocardial biopsy specimens. Circulation, 2007, 115(7), 896.

[46] Garry, D.J.; Olson, E.N. A common progenitor at the heart of development. Cell, 2006, 127(6), 1101.

[47] Moretti, A.; Caron, L.; Nakano, A.; Lam, J.T.; Bernshausen, A.; Chen, Y.; Qyang, Y.; Bu, L.; Sasaki, M.; Martin-Puig, S.; Sun, Y.; Evans, S.M.; Laugwitz, K.L.; Chien, K.R. Multipotent embryonic isl1+ progenitor cells lead to cardiac, smooth muscle, and endothelial cell diversification. Cell, 2006, 127(6), 1151.

[48] Wu, S.M.; Fujiwara, Y.; Cibulsky, S.M.; Clapham, D.E.; Lien, C.L.; Schultheiss, T.M.; Orkin, S.H. Developmental origin of a bipotential myocardial and smooth muscle cell precursor in the mammalian heart. Cell, 2006, 127(6), 1137.

[49] Kattman, S.J.; Huber, T.L.; Keller, G.M. Multipotent flk-1+ cardiovascular progenitor cells give rise to the cardiomyocyte, endothelial, and vascular smooth muscle lineages. Dev. Cell, 2006, $11(5), 723$.

[50] Urbanek, K.; Cesselli, D.; Rota, M.; Nascimbene, A.; De Angelis, A.; Hosoda, T.; Bearzi, C.; Boni, A.; Bolli, R.; Kajstura, J.; Anversa, P.; Leri, A. Stem cell niches in the adult mouse heart. Proc. Natl. Acad. Sci. USA, 2006, 103(24), 9226.

[51] Barile, L.; Cerisoli, F.; Gaetani, R.; Forte, E.; Ottolenghi, S.; Magli, M.C.; Messina, E. Cardiac stem cells can be generated in damaged heart from bone marrow-derived cells. J. Mole. Cell Cardiol., 2007, 42(Suppl. 1), S100.

[52] Zammaretti, P.; Jaconi, M. Cardiac tissue engineering: regeneration of the wounded heart. Curr. Opin. Biotechnol., 2004, 15(5), 430.

[53] Zimmermann, W.H.; Didie, M.; Doker, S.; Melnychenko, I.; Naito, H.; Rogge, C.; Tiburcy, M.; Eschenhagen, T. Heart muscle engineering: an update on cardiac muscle replacement therapy. Cardiovasc. Res., 2006, $71(3), 419$.

[54] Jawad, H.; Ali, N.N.; Lyon, A.R.; Chen, Q.Z.; Harding, S.E.; Boccaccini, A.R. Myocardial tissue engineering: a review. J. Tissue Eng. Regen. Med., 2007, 1(5), 327.

[55] Leor, J.; Aboulafia-Etzion, S.; Dar, A.; Shapiro, L.; Barbash, I.M.; Battler, A.; Granot, Y.; Cohen, S. Bioengineered cardiac grafts: a new approach to repair the infarcted myocardium? Circulation, 2000, 102(19 Suppl. 3), III56.

[56] Pego, A.P.; Van Luyn, M.J.; Brouwer, L.A.; van Wachem, P.B.; Poot, A.A.; Grijpma, D.W.; Feijen, J. In vivo behavior of poly(1,3trimethylene carbonate) and copolymers of 1,3-trimethylene carbonate with D,L-lactide or epsilon-caprolactone: degradation and tissue response. J. Biomed. Mater. Res. A, 2003, 67(3), 1044.

[57] Matsubayashi, K.; Fedak, P.W.; Mickle, D.A.; Weisel, R.D.; Ozawa, T.; Li, R.K. Improved left ventricular aneurysm repair with bioengineered vascular smooth muscle grafts. Circulation, 2003, 108(Suppl. 1), II219.

[58] Piao, H.; Kwon, J.S.; Piao, S.; Sohn, J.H.; Lee, Y.S.; Bae, J.W.; Hwang, K.K.; Kim, D.W.; Jeon, O.; Kim, B.S.; Park, Y.B.; Cho, M.C. Effects of cardiac patches engineered with bone marrowderived mononuclear cells and PGCL scaffolds in a rat myocardial infarction model. Biomaterials, 2007, 28(4), 641.

[59] Shimizu, T.; Yamato, M.; Akutsu, T.; Shibata, T.; Isoi, Y.; Kikuchi, A.; Umezu, M.; Okano, T. Electrically communicating threedimensional cardiac tissue mimic fabricated by layered cultured cardiomyocyte sheets. J. Biomed. Mater. Res., 2002, 60(1), 110.

[60] Shimizu, T.; Yamato, M.; Isoi, Y.; Akutsu, T.; Setomaru, T.; Abe, K.; Kikuchi, A.; Umezu, M.; Okano, T. Fabrication of pulsatile cardiac tissue grafts using a novel 3-dimensional cell sheet manipulation technique and temperature-responsive cell culture surfaces. Circ. Res., 2002, 90(3), e40.

[61] Shimizu, T.; Yamato, M.; Kikuchi, A.; Okano, T. Cell sheet engineering for myocardial tissue reconstruction. Biomaterials, 2003, 24(13), 2309.

[62] Zimmermann, W.H.; Didie, M.; Wasmeier, G.H.; Nixdorff, U.; Hess, A.; Melnychenko, I.; Boy, O.; Neuhuber, W.L.; Weyand, M.; Eschenhagen, T. Cardiac grafting of engineered heart tissue in syngenic rats. Circulation, 2002, 106 (12 Suppl. 1), I151.

[63] Zimmermann, W.H.; Melnychenko, I.; Wasmeier, G.; Didie, M.; Naito, H.; Nixdorff, U.; Hess, A.; Budinsky, L.; Brune, K.; Micha- elis, B.; Dhein, S.; Schwoerer, A.; Ehmke, H.; Eschenhagen, T. Engineered heart tissue grafts improve systolic and diastolic function in infarcted rat hearts. Nat. Med., 2006, 12(4), 452.

[64] Kofidis, T.; Akhyari, P.; Boublik, J.; Theodorou, P.; Martin, U.; Ruhparwar, A.; Fischer, S.; Eschenhagen, T.; Kubis, H.P.; Kraft, T.; Leyh, R.; Haverich, A. In vitro engineering of heart muscle: artificial myocardial tissue. J. Thorac. Cardiovasc. Surg., 2002, 124(1), 63.

[65] Kofidis, T.; Akhyari, P.; Wachsmann, B.; Boublik, J.; MuellerStahl, K.; Leyh, R.; Fischer, S.; Haverich, A. A novel bioartificial myocardial tissue and its prospective use in cardiac surgery. Eur. $J$. Cardiothorac. Surg., 2002, 22(2), 238

[66] Kofidis, T.; Lenz, A.; Boublik, J.; Akhyari, P.; Wachsmann, B.; Stahl, K.M.; Haverich, A.; Leyh, R.G. Bioartificial grafts for transmural myocardial restoration: a new cardiovascular tissue culture concept. Eur. J. Cardiothorac. Surg., 2003, 24(6), 906.

[67] Kofidis, T.; Akhyari, P.; Wachsmann, B.; Mueller-Stahl, K.; Boublik, J.; Ruhparwar, A.; Mertsching, H.; Balsam, L.; Robbins, R.; Haverich, A. Clinically established hemostatic scaffold (tissue fleece) as biomatrix in tissue- and organ-engineering research. Tissue Eng., 2003, 9(3), 517.

[68] Kofidis, T.; de Bruin, J.L.; Hoyt, G.; Ho, Y.; Tanaka, M.; Yamane, T.; Lebl, D.R.; Swijnenburg, R.J.; Chang, C.P.; Quertermous, T.; Robbins, R.C. Myocardial restoration with embryonic stem cell bioartificial tissue transplantation. J. Heart Lung Transplant., 2005, 24(6), 737

[69] Cortes-Morichetti, M.; Frati, G.; Schussler, O.; Van Huyen, J.P.; Lauret, E.; Genovese, J.A.; Carpentier, A.F.; Chachques, J.C. Association between a cell-seeded collagen matrix and cellular cardiomyoplasty for myocardial support and regeneration. Tissue Eng., 2007, 13(11), 2681.

[70] Akhyari, P.; Fedak, P.W.; Weisel, R.D.; Lee, T.Y.; Verma, S.; Mickle, D.A.; Li, R.K. Mechanical stretch regimen enhances the formation of bioengineered autologous cardiac muscle grafts. Circulation, 2002, 106 (12 Suppl. 1), I137.

[71] Chachques, J.C.; Trainini, J.C.; Lago, N.; Cortes-Morichetti, M.; Schussler, O.; Carpentier, A. Myocardial Assistance by Grafting a New Bioartificial Upgraded Myocardium (MAGNUM trial): clinical feasibility study. Ann. Thorac. Surg., 2008, 85(3), 901.

[72] Christman, K.L.; Vardanian, A.J.; Fang, Q.; Sievers, R.E.; Fok, H.H.; Lee, R.J. Injectable fibrin scaffold improves cell transplant survival, reduces infarct expansion, and induces neovasculature formation in ischemic myocardium. J. Am. Coll. Cardiol., 2004, 44(3), 654

[73] Li, Y.S.; Gao, B.R. Transplantation of neonatal cardiomyocytes plus fibrin sealant restores myocardial function in a rat model of myocardial infarction. Chin. Med. J. (Engl.), 2007, 120(22), 2022.

[74] Huang, N.F.; Yu, J.; Sievers, R.; Li, S.; Lee, R.J. Injectable biopolymers enhance angiogenesis after myocardial infarction. Tissue Eng., 2005, 11(11-12), 1860 .

[75] Suuronen, E.J.; Veinot, J.P.; Wong, S.; Kapila, V.; Price, J.; Griffith, M.; Mesana, T.G.; Ruel, M. Tissue-engineered injectable collagen-based matrices for improved cell delivery and vascularization of ischemic tissue using CD133+ progenitors expanded from the peripheral blood. Circulation, 2006, 114(1 Supp. 1), I138.

[76] Dai, W.; Wold, L.E.; Dow, J.S.; Kloner, R.A. Thickening of the infarcted wall by collagen injection improves left ventricular function in rats: a novel approach to preserve cardiac function after myocardial infarction. J. Am. Coll. Cardiol., 2005, 46(4), 714.

[77] Kutschka, I.; Chen, I.Y.; Kofidis, T.; Arai, T.; von Degenfeld, G.; Sheikh, A.Y.; Hendry, S. L.; Pearl, J.; Hoyt, G.; Sista, R.; Yang, P.C.; Blau, H.M.; Gambhir, S.S.; Robbins, R.C. Collagen matrices enhance survival of transplanted cardiomyoblasts and contribute to functional improvement of ischemic rat hearts. Circulation, 2006, 114(1 Suppl.), I167.

[78] Kofidis, T.; Lebl, D.R.; Martinez, E.C.; Hoyt, G.; Tanaka, M. Robbins, R.C. Novel injectable bioartificial tissue facilitates targeted, less invasive, large-scale tissue restoration on the beating heart after myocardial injury. Circulation, 2005, 112(9 Suppl.), I173.

[79] Davis, M.E.; Motion, J.P.; Narmoneva, D.A.; Takahashi, T.; Hakuno, D.; Kamm, R.D.; Zhang, S.; Lee, R.T. Injectable selfassembling peptide nanofibers create intramyocardial microenvironments for endothelial cells. Circulation, 2005, 111(4), 442. 
[80] Perin, E.C.; Lopez, J. Methods of stem cell delivery in cardiac diseases. Nat. Clin. Pract. Cardiovasc. Med., 2006, 3(Suppl. 1), S110.

[81] Dimmeler, S.; Zeiher, A.M.; Schneider, M.D. Unchain my heart: the scientific foundations of cardiac repair. J. Clin. Invest., 2005, $115(3), 572$.

[82] Davani, S.; Deschaseaux, F.; Chalmers, D.; Tiberghien, P.; Kantelip, J.P. Can stem cells mend a broken heart? Cardiovasc. Res., 2005, 65(2), 305.

[83] Ince, H.; Petzsch, M.; Kleine, H.D.; Schmidt, H.; Rehders, T.; Korber, T.; Schumichen, C.; Freund, M.; Nienaber, C.A. Preservation from left ventricular remodeling by front-integrated revascularization and stem cell liberation in evolving acute myocardial infarction by use of granulocyte-colony-stimulating factor (FIRSTLINE-AMI). Circulation, 2005, 112(20), 3097.

[84]. Ince, H.; Petzsch, M.; Kleine, H.D.; Eckard, H.; Rehders, T.; Burska, D.; Kische, S.; Freund, M.; Nienaber, C.A. Prevention of left ventricular remodeling with granulocyte colony-stimulating factor after acute myocardial infarction: final 1-year results of the FrontIntegrated Revascularization and Stem Cell Liberation in Evolving Acute Myocardial Infarction by Granulocyte Colony-Stimulating Factor (FIRSTLINE-AMI) Trial. Circulation, 2005, 112(9 Suppl.), I73.

[85] Engelmann, M.G.; Theiss, H.D.; Hennig-Theiss, C.; Huber, A.; Wintersperger, B.J.; Werle-Ruedinger, A.E.; Schoenberg, S.O.; Steinbeck, G.; Franz, W.M. Autologous bone marrow stem cell mobilization induced by granulocyte colony-stimulating factor after subacute ST-segment elevation myocardial infarction undergoing late revascularization: final results from the G-CSF-STEMI (Granulocyte Colony-Stimulating Factor ST-Segment Elevation Myocardial Infarction) trial. J. Am. Coll. Cardiol., 2006, 48(8), 1712.

[86] Ripa, R.S.; Jorgensen, E.; Wang, Y.; Thune, J.J.; Nilsson, J.C.; Sondergaard, L.; Johnsen, H. E.; Kober, L.; Grande, P.; Kastrup, J. Stem cell mobilization induced by subcutaneous granulocytecolony stimulating factor to improve cardiac regeneration after acute ST-elevation myocardial infarction: result of the doubleblind, randomized, placebo-controlled stem cells in myocardial infarction (STEMMI) trial. Circulation, 2006, 113(16), 1983.

[87] Ripa, R.S.; Haack-Sorensen, M.; Wang, Y.; Jorgensen, E.; Mortensen, S.; Bindslev, L.; Friis, T.; Kastrup, J. Bone marrow derived mesenchymal cell mobilization by granulocyte-colony stimulating factor after acute myocardial infarction: results from the Stem Cells in Myocardial Infarction (STEMMI) trial. Circulation, 2007, 116(11 Suppl.), I24.

[88] Zohlnhofer, D.; Ott, I.; Mehilli, J.; Schomig, K.; Michalk, F.; Ibrahim, T.; Meisetschlager, G.; von Wedel, J.; Bollwein, H.; Seyfarth, M.; Dirschinger, J.; Schmitt, C.; Schwaiger, M.; Kastrati, A.; Schomig, A. Stem cell mobilization by granulocyte colonystimulating factor in patients with acute myocardial infarction: a randomized controlled trial. JAMA, 2006, 295(9), 1003.

[89] Menasche, P.; Hagege, A.A.; Vilquin, J.T.; Desnos, M.; Abergel, E.; Pouzet, B.; Bel, A.; Sarateanu, S.; Scorsin, M.; Schwartz, K.; Bruneval, P.; Benbunan, M.; Marolleau, J.P.; Duboc, D. Autologous skeletal myoblast transplantation for severe postinfarction left ventricular dysfunction. J. Am. Coll. Cardiol., 2003, 41(7), 1078.

[90] Pagani, F.D.; DerSimonian, H.; Zawadzka, A.; Wetzel, K.; Edge, A.S.; Jacoby, D.B.; Dinsmore, J.H.; Wright, S.; Aretz, T.H.; Eisen, H.J.; Aaronson, K.D. Autologous skeletal myoblasts transplanted to ischemia-damaged myocardium in humans. Histological analysis of cell survival and differentiation. J. Am. Coll. Cardiol., 2003, 41(5), 879 .

[91] Hagege, A.A.; Vilquin, J.T.; Bruneval, P.; Menasche, P. Regeneration of the myocardium: a new role in the treatment of ischemic heart disease? Hypertension, 2001, 38(6), 1413.

[92] Makkar, R.R.; Lill, M.; Chen, P.S. Stem cell therapy for myocardial repair: is it arrhythmogenic? J. Am. Coll. Cardiol., 2003, 42(12), 2070.

[93] Abraham, M.R.; Henrikson, C.A.; Tung, L.; Chang, M.G.; Aon, M.; Xue, T.; Li, R.A.; B, O. R.; Marban, E. Antiarrhythmic engineering of skeletal myoblasts for cardiac transplantation. Circ Res, 2005, 97(2), 159.

[94] Rubart, M.; Soonpaa, M.H.; Nakajima, H.; Field, L.J. Spontaneous and evoked intracellular calcium transients in donor-derived myo- cytes following intracardiac myoblast transplantation. J. Clin. Invest., 2004, 114(6), 775.

[95] Assmus, B.; Schachinger, V.; Teupe, C.; Britten, M.; Lehmann, R.; Dobert, N.; Grunwald, F.; Aicher, A.; Urbich, C.; Martin, H.; Hoelzer, D.; Dimmeler, S.; Zeiher, A.M. Transplantation of Progenitor Cells and Regeneration Enhancement in Acute Myocardial Infarction (TOPCARE-AMI). Circulation, 2002, 106(24), 3009.

[96] Schachinger, V.; Assmus, B.; Britten, M.B.; Honold, J.; Lehmann, R.; Teupe, C.; Abolmaali, N.D.; Vogl, T.J.; Hofmann, W.K.; Martin, H.; Dimmeler, S.; Zeiher, A.M. Transplantation of progenitor cells and regeneration enhancement in acute myocardial infarction: final one-year results of the TOPCARE-AMI Trial. J. Am. Coll. Cardiol., 2004, 44(8), 1690.

[97] Wollert, K.C.; Meyer, G.P.; Lotz, J.; Ringes-Lichtenberg, S.; Lippolt, P.; Breidenbach, C.; Fichtner, S.; Korte, T.; Hornig, B.; Messinger, D.; Arseniev, L.; Hertenstein, B.; Ganser, A.; Drexler, H. Intracoronary autologous bone-marrow cell transfer after myocardial infarction: the BOOST randomised controlled clinical trial. Lancet, 2004, 364(9429), 141.

[98] Meyer, G.P.; Wollert, K.C.; Lotz, J.; Steffens, J.; Lippolt, P.; Fichtner, S.; Hecker, H.; Schaefer, A.; Arseniev, L.; Hertenstein, B.; Ganser, A.; Drexler, H. Intracoronary bone marrow cell transfer after myocardial infarction: eighteen months' follow-up data from the randomized, controlled BOOST (BOne marrOw transfer to enhance ST-elevation infarct regeneration) trial. Circulation, 2006, 113(10), 1287.

[99] Orlic, D.; Kajstura, J.; Chimenti, S.; Jakoniuk, I.; Anderson, S.M.; Li, B.; Pickel, J.; McKay, R.; Nadal-Ginard, B.; Bodine, D.M.; Leri, A.; Anversa, P. Bone marrow cells regenerate infarcted myocardium. Nature, 2001, 410(6829), 701.

[100] Kajstura, J.; Rota, M.; Whang, B.; Cascapera, S.; Hosoda, T.; Bearzi, C.; Nurzynska, D.; Kasahara, H.; Zias, E.; Bonafe, M.; Nadal-Ginard, B.; Torella, D.; Nascimbene, A.; Quaini, F.; Urbanek, K.; Leri, A.; Anversa, P. Bone marrow cells differentiate in cardiac cell lineages after infarction independently of cell fusion. Circ. Res., 2005, 96(1), 127.

[101] Jackson, K.A.; Majka, S.M.; Wang, H.; Pocius, J.; Hartley, C.J.; Majesky, M.W.; Entman, M. L.; Michael, L.H.; Hirschi, K.K.; Goodell, M.A. Regeneration of ischemic cardiac muscle and vascular endothelium by adult stem cells. J. Clin. Invest., 2001, 107(11), 1395.

[102] Murry, C.E.; Soonpaa, M.H.; Reinecke, H.; Nakajima, H.; Nakajima, H.O.; Rubart, M.; Pasumarthi, K.B.; Virag, J.I.; Bartelmez, S.H.; Poppa, V.; Bradford, G.; Dowell, J.D.; Williams, D. A.; Field, L.J. Haematopoietic stem cells do not transdifferentiate into cardiac myocytes in myocardial infarcts. Nature, 2004, 428(6983), 664.

[103] Balsam, L.B.; Wagers, A.J.; Christensen, J.L.; Kofidis, T.; Weissman, I.L.; Robbins, R.C. Haematopoietic stem cells adopt mature haematopoietic fates in ischaemic myocardium. Nature, 2004, 428(6983), 668.

[104] Pittenger, M.F.; Mackay, A.M.; Beck, S.C.; Jaiswal, R.K.; Douglas, R.; Mosca, J.D.; Moorman, M.A.; Simonetti, D.W.; Craig, S.; Marshak, D.R. Multilineage potential of adult human mesenchymal stem cells. Science, 1999, 284(5411), 143.

[105] Amado, L.C.; Saliaris, A.P.; Schuleri, K.H.; St John, M.; Xie, J.S.; Cattaneo, S.; Durand, D.J.; Fitton, T.; Kuang, J.Q.; Stewart, G.; Lehrke, S.; Baumgartner, W.W.; Martin, B.J.; Heldman, A.W.; Hare, J.M. Cardiac repair with intramyocardial injection of allogeneic mesenchymal stem cells after myocardial infarction. Proc. Natl. Acad. Sci. USA, 2005, 102(32), 11474.

[106] Hou, M.; Yang, K.M.; Zhang, H.; Zhu, W.Q.; Duan, F.J.; Wang, H.; Song, Y.H.; Wei, Y.J.; Hu, S.S. Transplantation of mesenchymal stem cells from human bone marrow improves damaged heart function in rats. Int. J. Cardiol., 2007, 115(2), 220.

[107] Dai, W.; Hale, S.L.; Martin, B.J.; Kuang, J.Q.; Dow, J.S.; Wold, L.E.; Kloner, R.A. Allogeneic mesenchymal stem cell transplantation in postinfarcted rat myocardium: short- and long-term effects. Circulation, 2005, 112(2), 214.

[108] Toma, C.; Pittenger, M.F.; Cahill, K.S.; Byrne, B.J.; Kessler, P.D. Human mesenchymal stem cells differentiate to a cardiomyocyte phenotype in the adult murine heart. Circulation, 2002, 105(1), 93.

[109] Shake, J.G.; Gruber, P.J.; Baumgartner, W.A.; Senechal, G.; Meyers, J.; Redmond, J.M.; Pittenger, M.F.; Martin, B.J. Mesenchymal stem cell implantation in a swine myocardial infarct model: en- 
graftment and functional effects. Ann. Thorac. Surg., 2002, 73(6), 1919.

[110] Kawamoto, A.; Gwon, H.C.; Iwaguro, H.; Yamaguchi, J.I.; Uchida, S.; Masuda, H.; Silver, M.; Ma, H.; Kearney, M.; Isner, J.M.; Asahara, T. Therapeutic potential of ex vivo expanded endothelial progenitor cells for myocardial ischemia. Circulation, 2001, 103(5), 634.

[111] Kocher, A.A.; Schuster, M.D.; Szabolcs, M.J.; Takuma, S.; Burkhoff, D.; Wang, J.; Homma, S.; Edwards, N.M.; Itescu, S. Neovascularization of ischemic myocardium by human bone-marrowderived angioblasts prevents cardiomyocyte apoptosis, reduces remodeling and improves cardiac function. Nat. Med., 2001, 7(4), 430 .

[112] Iwasaki, H.; Kawamoto, A.; Ishikawa, M.; Oyamada, A.; Nakamori, S.; Nishimura, H.; Sadamoto, K.; Horii, M.; Matsumoto, T.; Murasawa, S.; Shibata, T.; Suehiro, S.; Asahara, T. Dosedependent contribution of CD34-positive cell transplantation to concurrent vasculogenesis and cardiomyogenesis for functional regenerative recovery after myocardial infarction. Circulation, 2006, 113(10), 1311.

[113]. Reinecke, H.; Poppa, V.; Murry, C.E. Skeletal muscle stem cells do not transdifferentiate into cardiomyocytes after cardiac grafting. $J$. Mol. Cell Cardiol., 2002, 34(2), 241.

[114] Ghostine, S.; Carrion, C.; Souza, L.C.; Richard, P.; Bruneval, P.; Vilquin, J.T.; Pouzet, B.; Schwartz, K.; Menasche, P.; Hagege, A.A. Long-term efficacy of myoblast transplantation on regional structure and function after myocardial infarction. Circulation, 2002, 106(12 Suppl. 1), I131.

[115] Bearzi, C.; Rota, M.; Hosoda, T.; Tillmanns, J.; Nascimbene, A.; De Angelis, A.; Yasuzawa-Amano, S.; Trofimova, I.; Siggins, R.W.; Lecapitaine, N.; Cascapera, S.; Beltrami, A.P.; D'Alessandro, D.A.; Zias, E.; Quaini, F.; Urbanek, K.; Michler, R.E.; Bolli, R.; Kajstura, J.; Leri, A.; Anversa, P. Human cardiac stem cells. Proc. Natl. Acad. Sci. USA, 2007, 104(35), 14068.

[116] Strauer, B.E.; Brehm, M.; Zeus, T.; Kostering, M.; Hernandez, A.; Sorg, R.V.; Kogler, G.; Wernet, P. Repair of infarcted myocardium by autologous intracoronary mononuclear bone marrow cell transplantation in humans. Circulation, 2002, 106(15), 1913.

[117] Assmus, B.; Honold, J.; Schachinger, V.; Britten, M.B.; FischerRasokat, U.; Lehmann, R.; Teupe, C.; Pistorius, K.; Martin, H.; Abolmaali, N.D.; Tonn, T.; Dimmeler, S.; Zeiher, A.M. Transcoronary transplantation of progenitor cells after myocardial infarction. N. Engl. J. Med., 2006, 355(12), 1222.

[118] Assmus, B.; Fischer-Rasokat, U.; Honold, J.; Seeger, F.H.; Fichtlscherer, S.; Tonn, T.; Seifried, E.; Schachinger, V.; Dimmeler, S.; Zeiher, A.M. Transcoronary transplantation of functionally competent BMCs is associated with a decrease in natriuretic peptide serum levels and improved survival of patients with chronic postinfarction heart failure: results of the TOPCARE-CHD Registry. Circ. Res., 2007, 100(8), 1234.

[119]. Schachinger, V.; Erbs, S.; Elsasser, A.; Haberbosch, W.; Hambrecht, R.; Holschermann, H.; Yu, J.; Corti, R.; Mathey, D. G.; Hamm, C. W.; Suselbeck, T.; Assmus, B.; Tonn, T.; Dimmeler, S.; Zeiher, A. M. Intracoronary bone marrow-derived progenitor cells in acute myocardial infarction. N. Engl. J. Med., 2006, 355(12), 1210.

[120] Schachinger, V.; Erbs, S.; Elsasser, A.; Haberbosch, W.; Hambrecht, R.; Holschermann, H.; Yu, J.; Corti, R.; Mathey, D.G.; Hamm, C.W.; Suselbeck, T.; Werner, N.; Haase, J.; Neuzner, J.; Germing, A.; Mark, B.; Assmus, B.; Tonn, T.; Dimmeler, S.; Zeiher, A.M. Improved clinical outcome after intracoronary administration of bone-marrow-derived progenitor cells in acute myocardial infarction: final 1-year results of the REPAIR-AMI trial. Eur. Heart J., 2006, 27(23), 2775.

[121] Fernandez-Aviles, F.; San Roman, J.A.; Garcia-Frade, J.; Fernandez, M.E.; Penarrubia, M.J.; de la Fuente, L.; Gomez-Bueno, M.; Cantalapiedra, A.; Fernandez, J.; Gutierrez, O.; Sanchez, P.L.; Hernandez, C.; Sanz, R.; Garcia-Sancho, J.; Sanchez, A. Experimental and clinical regenerative capability of human bone marrow cells after myocardial infarction. Circ. Res., 2004, 95(7), 742.

[122] Strauer, B.E.; Brehm, M.; Zeus, T.; Bartsch, T.; Schannwell, C.; Antke, C.; Sorg, R.V.; Kogler, G.; Wernet, P.; Muller, H.W.; Kostering, M. Regeneration of human infarcted heart muscle by intracoronary autologous bone marrow cell transplantation in chronic coronary artery disease: the IACT Study. J. Am. Coll. Cardiol., 2005, 46(9), 1651.

[123] Janssens, S.; Dubois, C.; Bogaert, J.; Theunissen, K.; Deroose, C.; Desmet, W.; Kalantzi, M.; Herbots, L.; Sinnaeve, P.; Dens, J.; Maertens, J.; Rademakers, F.; Dymarkowski, S.; Gheysens, O.; Van Cleemput, J.; Bormans, G.; Nuyts, J.; Belmans, A.; Mortelmans, L.; Boogaerts, M.; Van de Werf, F. Autologous bone marrow-derived stem-cell transfer in patients with ST-segment elevation myocardial infarction: double-blind, randomised controlled trial. Lancet, 2006, 367(9505), 113.

[124] Lunde, K.; Solheim, S.; Aakhus, S.; Arnesen, H.; Abdelnoor, M.; Forfang, K. Autologous stem cell transplantation in acute myocardial infarction: The ASTAMI randomized controlled trial. Intracoronary transplantation of autologous mononuclear bone marrow cells, study design and safety aspects. Scand. Cardiovasc. J., 2005, 39(3), 150.

[125] Lunde, K.; Solheim, S.; Aakhus, S.; Arnesen, H.; Abdelnoor, M.; Egeland, T.; Endresen, K.; Ilebekk, A.; Mangschau, A.; Fjeld, J. G.; Smith, H. J.; Taraldsrud, E.; Grogaard, H. K.; Bjornerheim, R.; Brekke, M.; Muller, C.; Hopp, E.; Ragnarsson, A.; Brinchmann, J. E.; Forfang, K. Intracoronary injection of mononuclear bone marrow cells in acute myocardial infarction. N. Engl. J. Med., 2006, 355(12), 1199.

[126] Chen, S.L.; Fang, W.W.; Ye, F.; Liu, Y.H.; Qian, J.; Shan, S.J.; Zhang, J.J.; Chunhua, R.Z.; Liao, L.M.; Lin, S.; Sun, J.P. Effect on left ventricular function of intracoronary transplantation of autologous bone marrow mesenchymal stem cell in patients with acute myocardial infarction. Am. J. Cardiol., 2004, 94(1), 92.

[127] Katritsis, D.G.; Sotiropoulou, P.A.; Karvouni, E.; Karabinos, I.; Korovesis, S.; Perez, S.A.; Voridis, E.M.; Papamichail, M. Transcoronary transplantation of autologous mesenchymal stem cells and endothelial progenitors into infarcted human myocardium. Catheter. Cardiovasc. Interv., 2005, 65(3), 321.

[128] Tse, H.F.; Kwong, Y.L.; Chan, J.K.; Lo, G.; Ho, C.L.; Lau, C.P. Angiogenesis in ischaemic myocardium by intramyocardial autologous bone marrow mononuclear cell implantation. Lancet, 2003, 361(9351), 47

[129] Perin, E.C.; Dohmann, H.F.; Borojevic, R.; Silva, S.A.; Sousa, A.L.; Mesquita, C.T.; Rossi, M.I.; Carvalho, A.C.; Dutra, H.S.; Dohmann, H.J.; Silva, G.V.; Belem, L.; Vivacqua, R.; Rangel, F. O.; Esporcatte, R.; Geng, Y.J.; Vaughn, W.K.; Assad, J.A.; Mesquita, E.T.; Willerson, J.T. Transendocardial, autologous bone marrow cell transplantation for severe, chronic ischemic heart failure. Circulation, 2003, 107(18), 2294.

[130] Perin, E.C.; Dohmann, H.F.; Borojevic, R.; Silva, S.A.; Sousa A.L.; Silva, G.V.; Mesquita, C. T.; Belem, L.; Vaughn, W.K.; Rangel, F.O.; Assad, J.A.; Carvalho, A.C.; Branco, R.V.; Rossi, M.I.; Dohmann, H.J.; Willerson, J.T. Improved exercise capacity and ischemia 6 and 12 months after transendocardial injection of autologous bone marrow mononuclear cells for ischemic cardiomyopathy. Circulation, 2004, $110(11$ Suppl. 1), II213.

[131] Fuchs, S.; Satler, L.F.; Kornowski, R.; Okubagzi, P.; Weisz, G.; Baffour, R.; Waksman, R.; Weissman, N.J.; Cerqueira, M.; Leon, M.B.; Epstein, S.E. Catheter-based autologous bone marrow myocardial injection in no-option patients with advanced coronary artery disease: a feasibility study. J. Am. Coll. Cardiol., 2003, 41(10), 1721.

[132] Stamm, C.; Westphal, B.; Kleine, H.D.; Petzsch, M.; Kittner, C.; Klinge, H.; Schumichen, C.; Nienaber, C.A.; Freund, M.; Steinhoff, G. Autologous bone-marrow stem-cell transplantation for myocardial regeneration. Lancet, 2003, 361(9351), 45.

[133] Stamm, C.; Kleine, H.D.; Westphal, B.; Petzsch, M.; Kittner, C.; Nienaber, C.A.; Freund, M.; Steinhoff, G. CABG and bone marrow stem cell transplantation after myocardial infarction. Thorac. Cardiovasc. Surg., 2004, 52(3), 152.

[134] Li, T.S.; Hamano, K.; Hirata, K.; Kobayashi, T.; Nishida, M. The safety and feasibility of the local implantation of autologous bone marrow cells for ischemic heart disease. J. Card. Surg., 2003, 18(Suppl. 2), S69.

[135] Kang, H.J.; Kim, H.S.; Zhang, S.Y.; Park, K.W.; Cho, H.J.; Koo, B.K.; Kim, Y.J.; Soo Lee, D.; Sohn, D.W.; Han, K.S.; Oh, B.H.; Lee, M.M.; Park, Y.B. Effects of intracoronary infusion of peripheral blood stem-cells mobilised with granulocyte-colony stimulating factor on left ventricular systolic function and restenosis after 
coronary stenting in myocardial infarction: the MAGIC cell randomised clinical trial. Lancet, 2004, 363(9411), 751.

[136] Kang, H.J.; Lee, H.Y.; Na, S.H.; Chang, S.A.; Park, K.W.; Kim, H.K.; Kim, S.Y.; Chang, H. J.; Lee, W.; Kang, W.J.; Koo, B.K.; Kim, Y.J.; Lee, D.S.; Sohn, D.W.; Han, K.S.; Oh, B.H.; Park, Y. B.; Kim, H.S. Differential effect of intracoronary infusion of mobilized peripheral blood stem cells by granulocyte colony-stimulating factor on left ventricular function and remodeling in patients with acute myocardial infarction versus old myocardial infarction: the MAGIC Cell-3-DES randomized, controlled trial. Circulation, 2006, 114(1 Suppl.), I145.

[137] Erbs, S.; Linke, A.; Adams, V.; Lenk, K.; Thiele, H.; Diederich, K.W.; Emmrich, F.; Kluge, R.; Kendziorra, K.; Sabri, O.; Schuler, G.; Hambrecht, R. Transplantation of blood-derived progenitor cells after recanalization of chronic coronary artery occlusion: first randomized and placebo-controlled study. Circ. Res., 2005, 97(8), 756.

[138] Erbs, S.; Linke, A.; Schuler, G.; Hambrecht, R. Intracoronary administration of circulating blood-derived progenitor cells after recanalization of chronic coronary artery occlusion improves endothelial function. Circ. Res., 2006, 98(5), e48.

[139] Boyle, A.J.; Whitbourn, R.; Schlicht, S.; Krum, H.; Kocher, A.; Nandurkar, H.; Bergmann, S.; Daniell, M.; O'Day, J.; Skerrett, D.; Haylock, D.; Gilbert, R. E.; Itescu, S. Intra-coronary high-dose CD34+ stem cells in patients with chronic ischemic heart disease: a 12-month follow-up. Int. J. Cardiol., 2006, 109(1), 21.

[140] Ozbaran, M.; Omay, S.B.; Nalbantgil, S.; Kultursay, H.; Kumanlioglu, K.; Nart, D.; Pektok, E. Autologous peripheral stem cell transplantation in patients with congestive heart failure due to ischemic heart disease. Eur. J. Cardiothorac. Surg., 2004, 25(3), 342.

[141] Pompilio, G.; Cannata, A.; Peccatori, F.; Bertolini, F.; Nascimbene, A.; Capogrossi, M.C.; Biglioli, P. Autologous peripheral blood stem cell transplantation for myocardial regeneration: a novel strategy for cell collection and surgical injection. Ann. Thorac. Surg., 2004, 78(5), 1808

[142] Losordo, D.W.; Schatz, R.A.; White, C.J.; Udelson, J.E.; Veereshwarayya, V.; Durgin, M.; Poh, K.K.; Weinstein, R.; Kearney, M.; Chaudhry, M.; Burg, A.; Eaton, L.; Heyd, L.; Thorne, T.; Shturman, L.; Hoffmeister, P.; Story, K.; Zak, V.; Dowling, D.; Traverse, J.H.; Olson, R.E.; Flanagan, J.; Sodano, D.; Murayama, T.; Kawamoto, A.; Kusano, K. F.; Wollins, J.; Welt, F.; Shah, P.; Soukas, P.; Asahara, T.; Henry, T.D. Intramyocardial transplantation of autologous CD34+ stem cells for intractable angina: a phase I/IIa double-blind, randomized controlled trial. Circulation, 2007, $115(25), 3165$.
[143] Briguori, C.; Reimers, B.; Sarais, C.; Napodano, M.; Pascotto, P.; Azzarello, G.; Bregni, M.; Porcellini, A.; Vinante, O.; Zanco, P.; Peschle, C.; Condorelli, G.; Colombo, A. Direct intramyocardial percutaneous delivery of autologous bone marrow in patients with refractory myocardial angina. Am. Heart J., 2006, 151(3), 674.

[144] Herreros, J.; Prosper, F.; Perez, A.; Gavira, J.J.; Garcia-Velloso, M.J.; Barba, J.; Sanchez, P. L.; Canizo, C.; Rabago, G.; MartiCliment, J.M.; Hernandez, M.; Lopez-Holgado, N.; GonzalezSantos, J.M.; Martin-Luengo, C.; Alegria, E. Autologous intramyocardial injection of cultured skeletal muscle-derived stem cells in patients with non-acute myocardial infarction. Eur. Heart J., 2003, 24(22), 2012.

[145] Gavira, J.J.; Herreros, J.; Perez, A.; Garcia-Velloso, M.J.; Barba, J.; Martin-Herrero, F.; Canizo, C.; Martin-Arnau, A.; Marti-Climent, J.M.; Hernandez, M.; Lopez-Holgado, N.; Gonzalez-Santos, J. M.; Martin-Luengo, C.; Alegria, E.; Prosper, F. Autologous skeletal myoblast transplantation in patients with nonacute myocardial infarction: 1-year follow-up. J. Thorac. Cardiovasc. Surg., 2006, 131(4), 799.

[146] Siminiak, T.; Kalawski, R.; Fiszer, D.; Jerzykowska, O.; Rzezniczak, J.; Rozwadowska, N.; Kurpisz, M. Autologous skeletal myoblast transplantation for the treatment of postinfarction myocardial injury: phase I clinical study with 12 months of follow-up. Am. Heart J., 2004, 148(3), 531.

[147] Dib, N.; Michler, R.E.; Pagani, F.D.; Wright, S.; Kereiakes, D.J.; Lengerich, R.; Binkley, P.; Buchele, D.; Anand, I.; Swingen, C.; Di Carli, M.F.; Thomas, J.D.; Jaber, W.A.; Opie, S.R.; Campbell, A.; McCarthy, P.; Yeager, M.; Dilsizian, V.; Griffith, B.P.; Korn, R.; Kreuger, S.K.; Ghazoul, M.; MacLellan, W.R.; Fonarow, G.; Eisen, H.J.; Dinsmore, J.; Diethrich, E. Safety and feasibility of autologous myoblast transplantation in patients with ischemic cardiomyopathy: four-year follow-up. Circulation, 2005, 112(12), 1748.

[148] Smits, P.C.; van Geuns, R.J.; Poldermans, D.; Bountioukos, M.; Onderwater, E.E.; Lee, C. H.; Maat, A.P.; Serruys, P.W. Catheterbased intramyocardial injection of autologous skeletal myoblasts as a primary treatment of ischemic heart failure: clinical experience with six-month follow-up. J. Am. Coll. Cardiol., 2003, 42(12), 2063.

[149] Ince, H.; Petzsch, M.; Rehders, T.C.; Chatterjee, T.; Nienaber, C.A Transcatheter transplantation of autologous skeletal myoblasts in postinfarction patients with severe left ventricular dysfunction. $J$. Endovasc. Ther., 2004, 11(6), 695.

[150] Siminiak, T.; Fiszer, D.; Jerzykowska, O.; Grygielska, B.; Rozwadowska, N.; Kalmucki, P.; Kurpisz, M. Percutaneous transcoronary-venous transplantation of autologous skeletal myoblasts in the treatment of post-infarction myocardial contractility impairment: the POZNAN trial. Eur. Heart J., 2005, 26(12), 1188. 